OPEN ACCESS

Edited by:

Charlotte Elisabeth Teunissen, VU University Medical Center Amsterdam, Netherlands

Reviewed by: Jesus Avila,

Centro de Biología Molecular Severo Ochoa, Spain

H. Bea Kuiperij, Radboud University Medical Center, Netherlands

*Correspondence: Alison L. Baird alison.baird@psych.ox.ac.uk Specialty section: This article was submitted to Neurodegeneration, a section of the journal Frontiers in Neurology

Received: 17 September 2015 Accepted: 26 October 2015 Published: 16 November 2015

Citation:

Baird AL, Westwood S and Lovestone S (2015) Blood-Based Proteomic Biomarkers of Alzheimer's

Disease Pathology.

Front. Neurol. 6:236.

doi: 10.3389/fneur.2015.00236

\section{Blood-Based Proteomic Biomarkers of Alzheimer's Disease Pathology}

\author{
Alison L. Baird*, Sarah Westwood and Simon Lovestone \\ Department of Psychiatry, University of Oxford, Oxford, UK
}

The complexity of Alzheimer's disease (AD) and its long prodromal phase poses challenges for early diagnosis and yet allows for the possibility of the development of disease modifying treatments for secondary prevention. It is, therefore, of importance to develop biomarkers, in particular, in the preclinical or early phases that reflect the pathological characteristics of the disease and, moreover, could be of utility in triaging subjects for preventative therapeutic clinical trials. Much research has sought biomarkers for diagnostic purposes by comparing affected people to unaffected controls. However, given that $A D$ pathology precedes disease onset, a pathology endophenotype design for biomarker discovery creates the opportunity for detection of much earlier markers of disease. Blood-based biomarkers potentially provide a minimally invasive option for this purpose and research in the field has adopted various "omics" approaches in order to achieve this. This review will, therefore, examine the current literature regarding bloodbased proteomic biomarkers of AD and its associated pathology.

Keywords: Alzheimer's disease, biomarkers, blood, proteomics, dementia

\section{INTRODUCTION}

Dementia is now a huge public health priority, with 115.4 million people worldwide estimated to be living with dementia by 2050 (1). These numbers are not only alarming on an individual level, but they are also unsustainable for our economy. Dementia costs the global economy US\$604 billion, and like prevalence rates this figure is also set to increase with an $85 \%$ rise in costs estimated by the year 2030 (2).

The most common form of dementia is Alzheimer's disease (AD), comprising approximately $50-70 \%$ of the elderly dementia population. AD is characterized by multiple cognitive deficits, which cause significant impairment to social or occupational functioning. The disease typically has a gradual onset followed by continuing cognitive decline, with a mean duration of approximately 8.5 years from the onset of clinical symptoms to the death of the patient (3).

Most clinical trials of potential therapeutic disease-modifying agents have involved individuals with clinically manifest dementia and have been relatively unsuccessful to date. Earlier stages of the disease are now being targeted, posing a challenge as it is difficult to detect individuals at this stage of $\mathrm{AD}$; brain pathology is developing silently and cognitive symptoms if detectable are subtle. The underlying neuropathology characteristic of $\mathrm{AD}$ precedes symptom onset by many years, with the accumulation of amyloid-beta (A $\beta$ ) plaques believed to occur 15-20 years in advance of clinical manifestation of the disease (4), followed by the aggregation of abnormally phosphorylated tau in neurofibrillary tangles. A biological marker (biomarker) of these pathologic processes could serve as an indicator of disease presence, pathology, and progression. Moreover, they could have great utility 
TABLE 1 | Search terms used for PubMed-based literature searches. Publications were filtered to include only studies in human species.

\begin{tabular}{|c|c|}
\hline Search & Search terms \\
\hline $\begin{array}{l}\text { Plasma } A \beta \text { and Tau as } \\
\text { biomarkers of } A D\end{array}$ & $\begin{array}{l}\text { [alzheimer }{ }^{\star} \text { (Title/Abstract) OR dementia(Title/Abstract) AND AD(Title/Abstract)] AND [blood(Title/Abstract) OR plasma(Title/Abstract) } \\
\text { OR serum(Title/Abstract)] AND [proteomic*(Title/Abstract) OR proteome(Title/Abstract) OR protein(Title/Abstract) OR proteins(Title/ } \\
\text { Abstract)] AND [biomarker (Title/Abstract) OR marker*(Title/Abstract)] AND [beta-amyloid(Title/Abstract) OR amyloid beta(Title/ } \\
\text { Abstract) OR abeta(Title/Abstract) OR tau(Title/Abstract)] }\end{array}$ \\
\hline $\begin{array}{l}\text { Plasma biomarkers of AD } \\
\text { (case-control studies) }\end{array}$ & $\begin{array}{l}\text { [alzheimer }{ }^{\star} \text { (Title/Abstract) OR dementia(Title/Abstract) AND AD(Title/Abstract)] AND [blood(Title/Abstract) OR plasma(Title/Abstract) } \\
\text { OR serum(Title/Abstract)] AND [proteomic*(Title/Abstract) OR proteome(Title/Abstract) OR protein(Title/Abstract) OR proteins(Title/ } \\
\text { Abstract)] AND [biomarker (Title/Abstract) OR marker*(Title/Abstract)] AND [diagnos(Title/Abstract) OR prognos(Title/Abstract) OR } \\
\text { progression(Title/Abstract)] }\end{array}$ \\
\hline $\begin{array}{l}\text { Plasma biomarkers of brain } \\
\text { atrophy }\end{array}$ & $\begin{array}{l}\text { [alzheimer*(Title/Abstract) OR dementia(Title/Abstract) AND AD(Title/Abstract)] AND [blood(Title/Abstract) OR plasma(Title/Abstract) } \\
\text { OR serum(Title/Abstract)] AND [proteomic*(Title/Abstract) OR proteome(Title/Abstract) OR protein(Title/Abstract) OR proteins(Title/ } \\
\text { Abstract)] AND [biomarker*(Title/Abstract) OR marker*(Title/Abstract)] AND [atrophy(Title/Abstract) OR brain volume(Title/Abstract) } \\
\text { OR sMRI(Title/Abstract) OR structural magnetic resonance imaging(Title/Abstract) OR structural MRI(Title/Abstract)] }\end{array}$ \\
\hline $\begin{array}{l}\text { Plasma biomarkers of } \\
\text { cognitive decline }\end{array}$ & $\begin{array}{l}\text { [alzheimer }{ }^{\star} \text { (Title/Abstract) OR dementia(Title/Abstract) AND AD(Title/Abstract)] AND [blood(Title/Abstract) OR plasma(Title/Abstract) } \\
\text { OR serum(Title/Abstract)] AND [proteomic*(Title/Abstract) OR proteome(Title/Abstract) OR protein(Title/Abstract) OR proteins(Title/ } \\
\text { Abstract)] AND [biomarker*(Title/Abstract) OR marker*(Title/Abstract)] AND [cognitive decline(Title/Abstract) OR cognition(Title/ } \\
\text { Abstract) OR MMSE(Title/Abstract) OR ADAS(Title/Abstract) OR CDR(Title/Abstract)] }\end{array}$ \\
\hline $\begin{array}{l}\text { Plasma biomarkers of PET } \\
\text { amyloid }\end{array}$ & $\begin{array}{l}\text { [alzheimer*(Title/Abstract) OR dementia(Title/Abstract) AND AD(Title/Abstract)] AND [blood(Title/Abstract) OR plasma(Title/Abstract) } \\
\text { OR serum(Title/Abstract)] AND [proteomic*(Title/Abstract) OR proteome(Title/Abstract) OR protein(Title/Abstract) OR proteins(Title/ } \\
\text { Abstract)] AND [biomarker*(Title/Abstract) OR marker*(Title/Abstract)] AND [pib(Title/Abstract) OR Pittsburgh compound b(Title/ } \\
\text { Abstract) OR florbetapir(Title/Abstract) OR flutemetamol(Title/Abstract) OR florbetaben(Title/Abstract) OR amyloid PET(Title/Abstract) } \\
\text { OR brain amyloid(Title/Abstract)] }\end{array}$ \\
\hline
\end{tabular}

in drug development and clinical trials, in particular for use in patient stratification and cohort enrichment.

In this review, we will discuss various studies that have utilized proteomic-based approaches to discover blood-based biomarkers for early and ideally preclinical detection of $\mathrm{AD}$ pathological processes and their use in clinical trials. We performed literature searches on PubMed ${ }^{1}$ using the search terms detailed in Table 1. The literature included for review was supplemented with other known applicable papers that were not identified in the searches.

\section{BIOMARKERS FOR AD}

Today, the biomarkers used most extensively in clinical trials for dementia and to some extent in clinical practice are structural magnetic resonance imaging (MRI), molecular imaging of amyloid deposition using positron emission tomography (PET), imaging of metabolism using fluoro-deoxy-D-glucose (FDG)-PET, and cerebrospinal fluid (CSF) measures of $A \beta$ and tau. However, structural changes measured using MRI are most likely relatively late events in the disease course and PET imaging is relatively expensive and limited in availability. Moreover, structural MRI and FDG-PET are not direct measures of the core pathological hallmarks of $\mathrm{AD}$ ( $\mathrm{A} \beta$ and tau) and may, therefore, be relatively non-specific for AD in some cases (5) (Figure 1).

The most well-characterized and validated tissue fluid molecular-based biomarker for $\mathrm{AD}$ is the decrease in $\mathrm{A} \beta$ and increase in tau and phospho-tau (pTau) observed in the CSF of people with $\mathrm{AD}$, with a number of studies documenting discrimination of AD patients from healthy controls with good sensitivity and specificity, as reviewed by others (6). However, the clinical utility

${ }^{1}$ http://www.ncbi.nlm.nih.gov/pubmed of this biomarker is limited by the relatively invasive nature of obtaining CSF (lumbar puncture), particularly from elderly individuals. This may limit its use in longitudinal studies or for clinical progression monitoring, for which repeated CSF measures would be required. Also, attention needs to be paid to standardization of measurement of these biomarkers, given that large inter-laboratory variation in the concentrations measured of these biomarkers are observed (7).

In a revised model of the temporal relationship between key biomarkers of $\mathrm{AD}$ pathology, Jack et al. (8) suggested that changes in CSF $A \beta_{1-42}$ are the earliest detectable biomarker of $\mathrm{AD}$ pathology, followed by the PET detection of changes in brain amyloid, changes in CSF tau levels, and finally MRI-based detection of hippocampal atrophy and FDG-PET measures of brain glucose metabolism, all of which occur prior to the emergence of clinical symptoms of the disease (8). This hypothesis is corroborated by the recent findings of a non-linear association between CSF A $\beta_{1-42}$ and florbetapir F-18 PET imaging of brain amyloid load at the extreme ends of the clinical scale, while strongest association is seen at the mid-range of clinically measured disease severity (9). These findings would suggest that the two measures could reflect different aspects of $\mathrm{AD} A \beta$ pathology, with PET ligands having poor affinity for diffuse plaques, which develop early. At this stage, the plaques retain $A \beta$ and, hence, CSF measures of $A \beta$ may be more sensitive than PET earlier on in the disease (9). It is, therefore, of importance to consider the sensitivity of these biomarkers in relation to the staging of disease when designing biomarker studies.

\section{BLOOD-BASED BIOMARKERS}

The minimally invasive and potentially inexpensive nature of tests using blood-based proteomic biomarkers make these approaches 


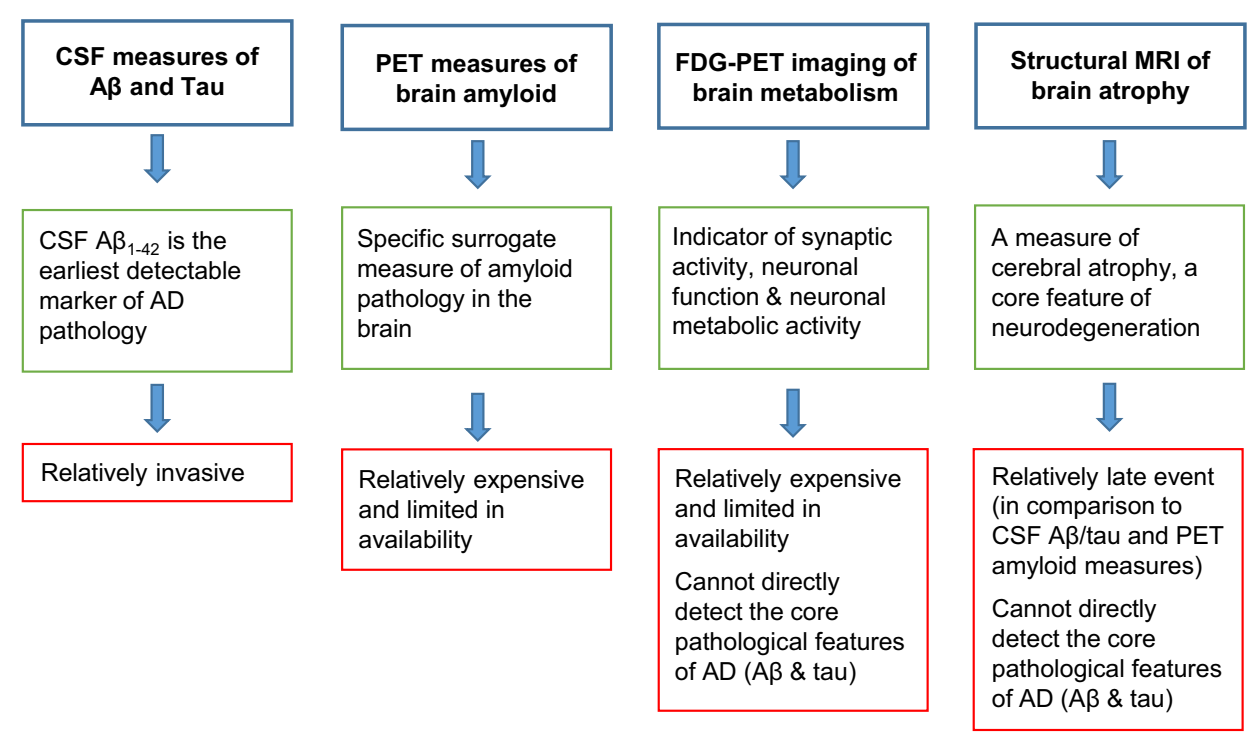

FIGURE 1 | Advantages (green boxes) and disadvantages (red boxes) of the biomarkers that are currently most widely used in clinical trials

practical to implement, allowing for repeated sampling in large cohorts, and, therefore, might have significant advantages over other biomarker modalities. However, the use of blood as a matrix for measurement of biomarkers has the inherent disadvantage of its complex composition and subsequently poses technical difficulties for biomarker detection.

The most challenging of many obstacles to developing bloodbased biomarkers is the massive dynamic range of proteins in blood, spanning up to 12 orders of magnitude (10). Furthermore, changes within the blood are often very small and reflect a wide range of both peripheral and central processes and, therefore, pinpointing $\mathrm{AD}$-specific changes can be challenging. Separated by the blood-brain barrier the relationship between analytes found in the blood and changes in the brain is still uncertain. However, with aging and in $\mathrm{AD}$, the blood-brain barrier is disrupted resulting in increased permeability, and this is thought to be a relatively early event in the aging brain, worsening with increased cognitive impairment (11). Blood-brain barrier disruption should only strengthen the relationship between blood and brain, and as an early event this would support the possibility of detecting protein-based markers related to $\mathrm{AD}$ at the early stages of disease. Nevertheless, concentrations of most known potential biomarkers are considerably lower in the blood than reported in CSF. For example, A $\beta$ peptide concentration is 100 -fold lower in blood than in CSF (12). Additionally, highly abundant plasma proteins such as albumin and IgG may mask the presence of less abundant proteins that may serve as potential biomarkers.

\section{TECHNIQUES FOR BLOOD-BASED BIOMARKER DISCOVERY}

The complexity of blood as a source of biomarkers is reflected in the limitations of various proteomic techniques that have been employed to investigate blood-based biomarkers for $\mathrm{AD}$.
In the following section, we will provide a brief overview of some of the tools available for proteomic biomarker discovery in blood, including mass spectrometry (MS), immunocapture, and aptamer-based techniques. Each of these approaches has their advantages and disadvantages and to date studies have combined a number of these approaches in the discovery pipeline for identifying protein biomarkers related to AD.

\section{Mass Spectrometry-Based Assays}

For discovery-level proteomics, a key attribute required of the technique used is the ability to measure multiple targets simultaneously in a multiplexing manner. MS-based approaches have been widely used in this way and possess the inherent advantage of there being no requirement for prior knowledge of the proteins being identified, hence, allowing for unbiased hypothesis-free biomarker discovery. Moreover, to facilitate multiplexing capabilities of MS-based protein quantification, approaches for labeling peptides or intact proteins have been developed, for example, the use of isobaric tags (13). This allows for the pooling of labeled samples for subsequent MS analysis, hence, increasing throughput. However, disadvantages of labeling may include increased complexity in sample preparation compared to label-free approaches. Furthermore, quantitative information can only be provided for peptides that contain the labeled amino acid, limiting the quantitative coverage of the sample to the labeled peptides alone.

However, the huge abundance of a select few proteins in plasma and serum limits the detection of lower molecular weight proteins by MS. In plasma and serum, albumin and the immunoglubulins (IgG, IgA, IgM, and $\operatorname{IgD}$ ) represent $75 \%$ of the total protein weight, and $99 \%$ of these samples are constituted by only 22 different protein species (14). Fractionation of the sample is one of the approaches that can be taken to reduce this sample complexity (15). Immunoaffinity-based depletion of the most abundant proteins is another approach that can be used to 
improve the detection of lower molecular weight proteins and the use of several different immunoaffinity depletion reagents have been documented (16-18). However, a disadvantage of depletion is the potential removal of lower molecular weight proteins, in addition to the high molecular weight targets for depletion. This is mainly an issue due to the binding nature of the protein targets for depletion, such as albumin, and, therefore, by removal of albumin, inadvertently albumin-bound lower molecular weight proteins may also be removed.

\section{Immunocapture-Based Assays}

The gold standard for soluble protein quantification is ELISA. However, with the increasing need to measure multiple protein targets, with limited sample availability, multiplexing approaches for targeted and hypothesis-driven biomarker discovery are now increasingly being used. Two of the most widely used immunocapture-based multiplexing systems for this purpose are mesoscale discovery (MSD) and the Luminex xMAP technology.

Both MSD and Luminex xMAP technologies are similar to the "sandwich" ELISA in priniciple. However, in an MSD assay, the capture antibodies are coated on specific spot regions at the base of the wells of a microtiter plate. Capture antibodies for different targets can be coated on each of the different spots, thus, allowing for multiple protein targets to be captured simultaneously in a single sample. Electrochemiluminescence (SULFO-TAG) labels are then bound to the detection antibodies and upon electrical stimulation the SULFO-TAG labels emit light, which is used to quantify the amount of target protein present. Luminex xMAP assays, in contrast, use microsphere-based technology, which involves coating of the capture antibody to microspheres "beads" in suspension, and fluorescently labeled detection antibodies for detection and quantification. In this way, multiple beads may be coated with multiple capture antibodies for multiplexing protein measurements in a single sample. Whichever approach to multiplexed affinity capture is used, the method is dependent on the quality, binding characteristics, and batch stability of the primary (and indeed secondary) antibodies used.

Given the targeted nature of immunocapture-based assays, these approaches are not necessarily suitable for unbiased hypothesis-free approaches for biomarker discovery. Furthermore, protein quantification by immunocapture methods will be epitope specific, and the quantitative values obtained will relate to the region of the protein recognized by the antibodies used within the assay. This is an important property to note when using immunocapture-based methods for replication of findings that may have been discovered on a different methodological platform, such as MS. Where failure to technically replicate data between platforms is observed, it could be due to differences in the region of the protein being recognized by the different assays. Platform and assay differences in protein quantification are, therefore, important points to consider when designing the pipeline for biomarker discovery and development.

\section{Aptamer-Based Assays}

Aptamer-based approaches also provide another approach for relative quantification of multiple proteins in a multiplexing manner. Aptamers are single-stranded oligonucleotides, which recognize and bind target proteins with high affinity and specificity. Using this technology, the protein signal is effectively transformed to a nucleotide signal for subsequent microarray-based quantification of the relative fluorescence levels. An example of this approach is the panel that Somalogic has developed, which measures over 1300 analytes in a single sample ${ }^{2}$. Advantages of this technology are clearly the large and unrivaled number of protein targets that can be quantified simultaneously in a single sample, making this platform ideal for extensive proteomic analysis in samples of limited availability. However, proteins quantified in this way are limited to those for which aptamers have been designed just as immunoaffinity approaches are limited by antibody availability.

Each of the proteomic techniques described here have inherent advantages and disadvantages for both hypothesis-generating and hypothesis-driven biomarker discovery. Furthermore, as described earlier, platform and assay differences may impact upon the ability to technically replicate findings at the discovery level, and should, therefore, be considered carefully when designing biomarker studies.

\section{BLOOD-BASED MEASURES OF A $\beta$ AND TAU}

In the CSF, $\mathrm{A} \beta_{42}$ (along with tau and pTau) shows good sensitivity and specificity for classifying $\mathrm{AD}$ patients from healthy controls (19). Given the success in developing CSF markers of A $\beta$ and tau as biomarkers it is unsurprising, therefore, that parallel approaches have been attempted in blood.

\section{Amyloid Beta}

Amyloid-beta fragments are produced by $\beta$ and $\gamma$-secretase metabolism of the protein APP. $\beta$-secretase cleavage of APP produces sAPP $\beta$ and a 99 amino acid membrane bound fragment, which upon subsequent $\gamma$-secretase cleavage produces various $\mathrm{A} \beta$ species (20). Of these $A \beta$ species, $A \beta_{40}$ is the most abundant, while the highly hydrophobic and insoluble $A \beta_{42}$ is the principal component of amyloid plaques in the AD brain (21), although deposition of insoluble $A \beta_{40}$ in plaques of the $\mathrm{AD}$ brain has also been observed (22).

To date, $A \beta_{42}$ and $A \beta_{40}$ are the predominant species that have been investigated in blood, however, as reviewed extensively by others $(23,24)$, the results of these studies have been somewhat contradictory. To illustrate this, a reduction in plasma levels of $A \beta_{42}$ in mild cognitive impairment (MCI) and $A D$ subjects compared to healthy controls has been shown (25), while no difference between $\mathrm{AD}$ and cognitively healthy controls in serum $\mathrm{A} \beta_{42}$ has also been reported by others (26).

In terms of disease progression, the results are equally contradictory. An association of decreased plasma $A \beta_{42}$ with more rapid cognitive decline in $\mathrm{AD}$ (27), progression from healthy to MCI (28), and conversion from MCI to AD (29) has been shown. Yet an opposite trend has also been reported, including increased $\mathrm{A} \beta_{42}$ with conversion from cognitively healthy to MCI (30) and elevated baseline plasma $A \beta_{42}$ in participants who converted to

${ }^{2}$ www.somalogic.com 
$\mathrm{AD}$ versus participants who remained cognitively healthy over a 5-year period (31). Moreover, Mayeux et al. showed that the increase in plasma $A \beta_{42}$ was followed by a decrease in individuals with the onset of $\mathrm{AD}$ (31), a pattern that has been mirrored in healthy elderly participants, who demonstrated higher baseline plasma $A \beta_{42}$ followed by greater reductions in plasma $A \beta_{42}$ with cognitive decline (32).

The results of blood $\mathrm{A} \beta_{40}$ as an $\mathrm{AD}$ biomarker have also been conflicting and are perhaps not as promising as that of $A \beta_{42}$. For example, both increased serum $A \beta_{40}(26,33)$ and decreased plasma $A \beta_{40}$ (34) have been shown in $A D$ versus healthy controls. Reduced levels of plasma $A \beta_{40}$ have also been associated with more rapid cognitive decline in $\mathrm{AD}$ (27), while no change in plasma $\mathrm{A} \beta_{40}$ between cognitively stable MCI and MCI to AD converters (29) or association with risk of developing dementia (35) have been observed.

Given the differing results of plasma $A \beta_{42}$ and $A \beta_{40}$ in relation to $\mathrm{AD}$, it is not surprising that studies examining the potential of $\mathrm{A} \beta_{42} / \mathrm{A} \beta_{40}$ in blood as an $\mathrm{AD}$ marker have also been conflicting in their results. A number of studies have documented reduced plasma $\mathrm{A} \beta_{42} / \mathrm{A} \beta_{40}$ in association with $\mathrm{AD}$-related parameters, including in $\mathrm{MCI}$ and $\mathrm{AD}$ subjects compared to healthy controls $(25,28)$, with progression from MCI to AD compared to cognitively stable MCI (29) and with risk of developing MCI and AD (36). However, increased plasma $A \beta_{42} / A \beta_{40}$ has also been related to increased risk of developing $\mathrm{AD}$ (37).

Very recently, however, a much larger, prospective, community-based study examined the levels of plasma $A \beta_{42}$ and $A \beta_{40}$ in over 2000 dementia-free individuals, and followed these individuals for dementia/AD over an 8-year period (35). In this study, Chouraki et al., found that lower levels of plasma $\mathrm{A} \beta_{42}$ were associated with an increased risk of developing dementia, which given the size of the study may be one of the most promising plasma $A \beta$ results to date.

The conflicting findings of different $\mathrm{A} \beta$ studies may perhaps suggest that the utility of plasma $A \beta$ as a marker is quite diseasestage specific, as postulated by Blasko et al. Their findings of a relationship of plasma $A \beta$ with conversion from cognitively healthy to MCI, but not later in the disease course when participants convert from $\mathrm{MCI}$ to $\mathrm{AD}$, would indicate that plasma $\mathrm{A} \beta$ may be more successful as a marker of pathology at the preclinical stages of disease. This theory would also be in line with why plasma $\mathrm{A} \beta_{42}$ appears to perform as a marker of risk for developing dementia over an 8-year period, as documented by Chouraki et al.

\section{Relationship Between Plasma and CSF A $\beta$}

Given that CSF A $\beta$ is normally cleared in blood (38), it could be hypothesized that a reduction in plasma $A \beta_{42}$ would be observed following the decrease observed in CSF $A \beta_{42}$ in late-onset $\mathrm{AD}$ (39). However, a number of studies have actually reported that CSF and plasma levels of $A \beta_{42}$ and $A \beta_{40}$ do not correlate well (40-42). There are several theories that could be proposed to explain this. First, the relationship between CSF and plasma levels of A $\beta$ may only exist at specific stages of the disease, relating to the degree of aggregation of brain amyloid in plaques. Second, it is thought that plasma $\mathrm{A} \beta$ may have a causal role in the development of microvascular dysfunction (43) and given the considerable incidence of cerebrovascular pathology in the AD brain (44), it has been proposed that this heterogeneity in pathology could also impact upon the levels of $A \beta$ measured in blood.

\section{Plasma A $\beta$ and Neuropathology}

The relationship between plasma $\mathrm{A} \beta$ and brain pathology is also not yet resolved. Levels of $A \beta_{40}$ and $A \beta_{42} 1$ year prior to postmortem brain tissue collection were not associated with frontal and temporal necortex $A \beta_{40}$ and $A \beta_{42}$ burden at post mortem (45). However, using PET measures of brain amyloid burden does suggest a relationship between plasma $A \beta$ and brain amyloid load, with an association between reduced plasma $A \beta_{42} / A \beta_{40}$ and increased brain amyloid load being shown $(28,46,47)$. Moreover, the ratio of the plasma proteins APP669-711 (cleavage product of the amyloid precursor protein) and $A \beta_{42}$ was increased in individuals of high amyloid burden subjects and demonstrated good sensitivity and specificity (93 and 96\% respectively) for discrimination of amyloid negative and positive subjects (48).

These findings indicate a potential relationship between plasma $\mathrm{A} \beta$ species and the neuropathology of $\mathrm{AD}$, however, given the contradictory results of plasma $\mathrm{A} \beta$ as a marker of $\mathrm{AD}$ diagnosis and clinical progression, it is clear that further work is required in order to consolidate the findings. As mentioned earlier, potential theories for the variability in the blood $A \beta$ study results have been suggested and include disease-heterogeneity effects upon $\mathrm{A} \beta$ levels, and a disease-stage-specific nature of $\mathrm{A} \beta$ as a marker, with perhaps $A \beta$ acting as an effective marker of preclinical rather than established disease. While these are valid theories that likely are having an impact, they are not able to explain the full extent of variability between the different $A \beta$ study findings.

Important additional issues that likely contribute to the variability observed between studies are the technical challenges encountered with measuring $A \beta$. First, Abdullah et al. reported high intra-subject differences in plasma $A \beta$ measures, as assessed by ELISA in two to three separate blood samples retrieved within a 4-week period from each individual (26). This variation in part may be related to the performance of the $\mathrm{A} \beta$ assays, with perhaps variation in the measurements being introduced due to lack of sensitivity of these assays. However, it is worth noting that plasma A $\beta$ exhibits a circadian rhythm in its levels (49) and, therefore, in order to use $\mathrm{A} \beta$ as a reliable marker, standardization in time of sampling will be required.

Second, it should be noted that many of the studies documented here have assessed plasma $\mathrm{A} \beta$ by immunocapture-based approaches, including commercially available and in-house optimized ELISAs (25-27, 29-31, 33, 36, 37, 42, 45, 46), luminex xMAP assays $(25,28,35,41,42)$, and immunomagnetic reduction (IMR) assays (47). While ELISAs are the gold standard for protein quantification, it is possible that inter-study variation in the results could be introduced by the use of different assays, which use antibodies that recognize different epitopes of $A \beta$. In this situation, standardization in the assay used across studies so that blood $\mathrm{A} \beta$ measures were epitope specific would be advisable.

Another factor to be considered is the technical difficulties of measuring $A \beta$, which is present at low concentrations in blood and will readily bind other circulating proteins, such as albumin, lipoproteins, and complement factors (50). One way 
to help overcome this issue might, therefore, be to develop an assay that can measure both free and cell/protein-bound $A \beta$. This is an approach that has been used to develop the AB test, which quantifies $A \beta_{40}$ and $A \beta_{42}$ peptides that are free in plasma and bound to other proteins in plasma and blood cells ${ }^{3}$. The AB test shows promise for measuring $\mathrm{A} \beta$ in an $\mathrm{AD}$-based cohort (51). Chiu and colleagues also report quantification of plasma $\mathrm{A} \beta$ by another highly sensitive immunoassay, developed using a technology known as superconducting quantum interference device (SQUID) IMR assay. This technology is based on measuring the magnetic signals produced from nanoparticles, bound to the target molecule of interest and is able to detect plasma $A \beta$ levels as low as $1 \mathrm{pg} / \mathrm{ml}$ for $A \beta_{40}$ and $10 \mathrm{pg} / \mathrm{ml}$ for $A \beta_{42}$. This is lower than that of standard $A \beta_{42}$ ELISAs, of which the lower limit of detection is generally around $50 \mathrm{pg} / \mathrm{ml}$ (52). Furthermore, the SQUID-IMR technology involves the use of iron-nanoparticles and it has been suggested that the iron-chelating effect may inhibit $\mathrm{A} \beta$ oligomerization, hence, reducing the issue of non-quantifiable $\mathrm{A} \beta$ oligomers (52). While the results of these new assays for $\mathrm{A} \beta$ are promising, validation of these assays in further larger and independent cohort studies is required.

\section{Tau}

To date the investigation of plasma tau-based measures and their utility as biomarkers for AD have also been limited, primarily due to tau being an axonal protein and, therefore, of low abundance in blood. Efforts have, therefore, been made to develop more sensitive assays for detection and reliable quantification.

First, Henriksen et al. have reported measurement of specific tau fragments using an ELISA method. These assays quantified specific tau fragments in serum [ADAM10-generated fragment (Tau-A) and caspase-3-generated fragment (Tau-C)] $(53,54)$. Using this method, measures of serum Tau-A, Tau-C, and the Tau-A/Tau-C ratio were shown to be associated with cognitive change in $\mathrm{AD}$, although no association of the serum tau fragments with CSF tau and pTau were observed (54). A second approach that has been reported for measuring tau utilizes a digital arraybased technology (55). This approach involves the isolation and detection of single enzyme molecules using femtolitre-sized reaction chambers, known as single-molecule arrays (SiMOA). This method facilitates the detection of the target at low concentrations by ensuring that the fluorophores are confined to small volumes and, hence, the concentration of fluorescently labeled target is high (56). Using this assay, elevated levels of plasma tau in $\mathrm{AD}$ in comparison to controls and MCI were shown, although a considerable overlap in the range of plasma tau across the diagnostic groups was also found (55). Moreover, no correlation between plasma and CSF tau levels were observed (55). Lastly, Chiu and colleagues reported quantification of plasma Tau by SQUID-IMR (as described earlier for detection of plasma $A \beta$ ) and showed an increase in plasma tau in MCI and $\mathrm{AD}$, along with an association of plasma tau with clinical measures of cognition and regional brain volume (57). This is all early but promising work, and moving forward, as with blood $\mathrm{A} \beta$ measures, further

${ }^{3}$ www.araclon.com replication of these findings in larger independent cohorts will be crucial for ascertaining the robustness of blood-based tau as an AD-related biomarker.

\section{DISCOVERY OF BLOOD-BASED BIOMARKERS OF AD USING A CASE-CONTROL STUDY DESIGN}

Since the blood-brain barrier damage that occurs in AD would facilitate movement of proteins between brain and blood (58), research has also focused upon the detection of other blood-based proteins, in addition to $A \beta$ and tau, which may serve as markers for $\mathrm{AD}$. Using both untargeted and candidate-based proteomic approaches and a case-control study design, a substantial number of proteins related to a diagnosis of $\mathrm{AD}$ or MCI have been identified (33, 59-95).

However, a panel of proteins rather than single protein candidates may have greater sensitivity and specificity as a biomarker and may collectively better describe and characterize the disease and its pathology. A number of studies, including from our group, have, therefore, taken an approach of analyzing multivariate signatures for prediction of $\mathrm{AD}$ and/or MCI status, and have identified and evaluated different proteins that collectively demonstrate sensitivity and specificity for classifying $\mathrm{AD}$ and/or MCI to varying degrees (96-118).

Alzheimer's disease biomarker studies premised upon a casecontrol study design have been extensively reviewed by others $(119,120)$ and as would be expected, many of the candidates identified in these studies can be related to aspects of the disease pathology, for example, having roles in inflammatory and amyloidogenic processes.

These studies comparing established disease to non-disease or prediction of rate of progression in established disease are promising but of more value would be marker sets that detected preclinical or prodromal disease. One design enabling such discovery is the prediction of conversion from MCI by using historical samples from research cohort participants with MCI comparing those who subsequently converted to dementia in a given time-frame to those who did not. One of the first such studies identified an 18 plasma protein signature that not only classified AD from control subjects with $90 \%$ accuracy but was also able to predict MCI patients who would convert to AD within 5 years (97). However, replication of the 18 protein biomarker panel in subsequent studies has so far been unsuccessful $(103,121,122)$. Yang et al. also demonstrated prediction of MCI conversion to $\mathrm{AD}$ with $79 \%$ accuracy using a 60 protein biomarker set (123), while we identified a panel of 10 proteins that were shown to strongly associate with both the degree of disease severity and to predict MCI progression to AD with $87 \%$ accuracy (124). More recently, Apostolova et al. reported prediction of MCI progression to $\mathrm{AD}$ with $73 \%$ accuracy by plasma IL-6R combined with clinical measures and APOE genotype (125).

Although a number of plasma protein signatures of AD diagnosis, disease severity, and progression have been identified in discovery-based studies, a key concern for the field has been the lack of reproducibility of these results. As yet there has been no 
single blood-based proteomic signature that can successfully distinguish between $\mathrm{AD}$ and $\mathrm{MCI}$ and cognitively healthy elderly in a reproducible manner. The reason for such non-reproducibility is unknown. It might be the inherent heterogeneity of the disease and the differences, therefore, between cohort studies. It might also be technical variability, including assay variation and sample collection and curation variation, or it might be that the findings are in fact artifactual and there is no consistent proteomic signature to be found in blood. However, another reason for the failure to replicate might be the intrinsic limitation of case-control studies in a condition with such a long prodrome.

First, it is important to consider the heterogeneity of dementia and the extensive comorbidity and differential environmental exposure in the elderly. As well as multiple dementia conditions being hard to distinguish from each other, the $\mathrm{AD}$ group itself can be clinically heterogeneous as can MCI. Moreover, comorbid conditions are common in $\mathrm{AD}$, and might not only alter the blood proteome directly but the associated polypharmacy prevalent in the elderly could also have an impact.

Second, case-control-based studies have inherent limitations when the target of discovery is in prodromal, or, worse, preclinical disease. In the context of $\mathrm{AD}$ research, the goal of biomarker discovery is primarily to detect individuals harboring early pathological change but without manifest dementia, as these individuals might be the most likely to respond to disease modifying agents. And yet in case-control studies such individuals will be included in studies not in the "case" group but in the "control" group. Clearly, this study design is at best non-optimal and at worse, destined for failure.

The recent failure of phase III clinical trials of antibody therapies targeting amyloid pathology, in part probably due to the absence of brain amyloid pathology in a considerable proportion of the participants $(126,127)$, highlights the important role biomarkers predictive of core $\mathrm{AD}$ neuropathology could play in recruitment to clinical trials. However, the inevitable screen failures using such approaches would be costly and increase the time to recruitment. Therefore, the development of a minimally invasive blood-based biomarker of $\mathrm{AD}$ pathology could have real utility as a first pass or triage marker, to identify potential participants more likely to harbor pathology and to reduce screen failure and, hence, facilitate trials conduct.

\section{DISCOVERY OF BLOOD-BASED BIOMARKERS OF AD PATHOLOGY USING AN ENDOPHENOTYPE APPROACH}

Endophenotype-based approaches for blood-based biomarker discovery have begun to be implemented and have utilized various $\mathrm{AD}$-related measures to identify blood-based biomarkers reflective of disease activity and pathology, including at the preclinical stages. These studies have included endophenotypes defined by measures such as brain atrophy (structural MRI), rate of cognitive decline, and brain amyloid $\beta$ burden (Pittsburgh B (PiB) PET brain imaging), with change in PiB PET amyloid burden being the earliest event of these in the disease course. These studies have identified a number of different potential proteomic biomarkers (Tables 2 and 3 ).

\section{Blood-Based Biomarkers of Brain Atrophy and Rate of Cognitive Decline}

We began by focusing on endophenotype approaches using mostly the AddNeuroMed, a European multicentre study (143) and the neuroimaging substudy of the Baltimore Longitudinal Study for Aging (BLSA) (144). Two key pathology endophenotypes were employed; structural neuroimaging of atrophy as a proxy measure of in vivo pathology and rate of clinical progression (Table 2), which was calculated based on retrospective and prospective measures of cognitive decline.

In 2010, we published a study that utilized a 2DGE-MS/ MS-based approach to discover plasma protein markers of both of these outcome variables in $\mathrm{AD}$ (128). This work identified seven proteins (complement C3, $\gamma$-fibrinogen, serum albumin, complement factor-I, clusterin, $\alpha-1$-microglobulin, and serum amyloidP) that were able to explain $34 \%$ of the variance in hippocampal volume in $\mathrm{MCI}$ and $\mathrm{AD}$, and five proteins (complement component $\mathrm{C} 4 \mathrm{a}$, complement $\mathrm{C} 8$, clusterin, ApoA1, and transthyretin) that were able to discriminate fast from slow progressing $\mathrm{AD}$ groups. These proteins were then selected for replication studies, including in an independent $\mathrm{AD} / \mathrm{MCI} /$ control-based cohort, using an orthogonal immunoassay-based approach. In this study, we replicated the association of complement $\mathrm{C} 3$, complement factor-I, $\gamma$-fibrinogen and $\alpha$-1-microglobulin with brain atrophy, and along with complement $\mathrm{C} 3 \mathrm{a}$, these five proteins were able to explain $35 \%$ of whole brain volume in AD (129). In a separate study, we also replicated the association of transthyretin with an increased rate of cognitive decline in $\mathrm{AD}$ (136).

However, the most promising candidate marker identified in this discovery study was the protein clusterin, which associated with both hippocampal atrophy and clinical progression (128). We also showed in this same study but in an independent (AD/ $\mathrm{MCI} /$ control) cohort, an association of clusterin with cognitive measures and with brain atrophy, specifically in the entorhinal cortex and with PiB PET measures of fibrillary amyloid burden in the entorhinal cortex of a non-demented elderly cohort (128). While very recently increased plasma clusterin levels have been associated with increased risk of conversion to $\mathrm{AD}$ and rate of cognitive decline in an independent study (145). These findings indicate that changes in plasma clusterin may be an early event in the disease course, which occurs with amyloid deposition but prior (or without) onset of clinical symptoms. Moreover, in this same study, we demonstrated colocalization of clusterin with $A \beta$ in plaques in the brains of a transgenic mouse model of AD (TASTPM) (128), thus, adding further support to the theory that clusterin may be implicated in amyloid formation and clearance (146).

Adding weight to our hypothesis that changes in plasma clusterin were an early event, increased levels of plasma clusterin in association with slower rates of brain atrophy in MCI were demonstrated (131). However, to the contrary, Song et al. demonstrated an association of increased plasma clusterin with reduced white matter volume in $\mathrm{MCI} /$ cognitively healthy elderly over a 2 -year period (130). These findings are somewhat contradictory, and could be explained in part by the evidence for clusterin having both neuroprotective and pro-amyloidegenic properties, 
TABLE 2 | Summary of the significant findings of studies examining plasma protein markers of brain atrophy and rate of cognitive decline.

\begin{tabular}{|c|c|c|c|}
\hline Proteins & Outcome variables (subjects) & Analytical platform & Study \\
\hline \multicolumn{4}{|c|}{ Endophenotype: structural MRI measures of brain atrophy } \\
\hline C3, FGG, albumin, CFI, clusterin, A1M and SAP & Hippocampal atrophy (AD and $\mathrm{MCl})$ & 2DGE LC-MS/MS & $(128)$ \\
\hline C3, C3a, CFI, FGG, and A1M & Whole brain volume (AD) & ELISA and western blots & $(129)$ \\
\hline ApoB/ApoA1 ${ }^{a}, A p o C 3^{b}, A p o E^{b}$, and Clusterin ${ }^{b, c}$ & $\begin{array}{l}\text { Hippocampal volume }{ }^{\mathrm{a}} \text {, gray matter volume }{ }^{\mathrm{b}} \text {, and } \\
\text { white matter volume }{ }^{\mathrm{c}}(\mathrm{MCl} \text { and } \\
\text { non-demented elderly) }\end{array}$ & Luminex xMAP (Myriad RBM) & $(130)$ \\
\hline Clusterin & Rate of brain atrophy (multiple brain regions in $\mathrm{MCl}$ ) & ELISA & $(131)$ \\
\hline IL-1ra ${ }^{d} \mid L-6^{d}, I L-10^{d}, I L-13^{e}$, and TNF- $\alpha^{f}$ & $\begin{array}{l}\text { Ventricular volume } e^{d} \text {, entorhinal cortex volume }{ }^{e} \text {, and } \\
\text { whole brain volume }(A D)\end{array}$ & Luminex xMAP & $(132)$ \\
\hline MIP1 $\alpha$, IGFBP2, CgA, and cortisol & $\begin{array}{l}\text { SPARE-AD measures of brain atrophy (AD, } \mathrm{MCl} \text {, and } \\
\text { non-demented elderly) }\end{array}$ & Luminex xMAP (Myriad RBM) & $(133)$ \\
\hline $\begin{array}{l}\text { RANTES }{ }^{g}, N^{2} E^{g, h}, T^{g, h} \text {, clustering }{ }^{g}, A 1 A T^{h}, A p o C 3^{h} \text {, } \\
\text { ApoA } 1^{h}, A p o E^{h}, B D N F^{h} \text { and } A \beta_{40}{ }^{h}\end{array}$ & Atrophy in multiple brain regions $\left(\mathrm{MCl}^{9}\right.$ and $\left.\mathrm{AD}^{\mathrm{h}}\right)$ & Luminex xMAP & $(124)$ \\
\hline PPY, fetuin B, PSA-ACT, and ChkT & $\begin{array}{l}\text { Entorhinal cortex and hippocampal volume (AD, MCl, } \\
\text { and non-demented elderly) }\end{array}$ & SOMAscan & $(134)$ \\
\hline ApoE & Hippocampal volume (MCl, non demented elderly) & Luminex xMAP (Myriad RBM) & $(135)$ \\
\hline \multicolumn{4}{|l|}{ Endophenotype: rate of cognitive decline } \\
\hline C4a, C8, clusterin, ApoA1, and TTR & Rate of cognitive decline (AD) & 2DGE LC-MS/MS & $(128)$ \\
\hline ApoA1, ApoA2, $\mathrm{ApoH}$, and ApoB/ApoA1 ratio & Risk of cognitive decline (non-demented elderly) & Luminex xMAP (Myriad RBM & $(130)$ \\
\hline TTR & Rate of cognitive decline (AD) & ELISA & $(136)$ \\
\hline IL-4, IL-10, G-CSF, IL-2, IFN- $\gamma$, and PDGF & Rate of cognitive decline (AD) & Luminex xMAP & $(132)$ \\
\hline NCAM, sRAGE, and ICAM & Rate of cognitive decline (AD) & Luminex xMAP & $(124)$ \\
\hline Clusterin and NAP2 & Rate of cognitive decline (AD) & SOMAscan & $(134)$ \\
\hline
\end{tabular}

C3, complement C3; FGG, $\gamma$-fibrinogen; CF1, complement factor-l; A1M, $\alpha$-1-microglobulin; SAP, serum amyloid-P; C3a, complement C3a; ApoB, apolipoprotein B; ApoA1, apolipoprotein A1; ApoC3, apolipoprotein C3; ApoE, apolipoprotein E; ApoC4, apolipoprotein C4; IL-1ra, interleukin 1 receptor antagonist; IL-6, interleukin-6; IL-10, interleukin-10; IL-13, interleukin-13; TNF- $\alpha$, tumor necrosis factor alpha; MIP1 $\alpha$, macrophage inhibitory protein 1 $\alpha$; IGFBP2, insulin-like growth factor binding protein 2; CgA, chromogranin A; RANTES, regulated on activation normal T cell expressed and secreted; NSE, neuron-specific enolase; TTR, transthyretin; A1AT, alpha 1 antitrypsin; BDNF, brain derived neurotrophic factor; $A \beta_{40}$, amyloid beta 1-40; PPY, pancreatic polypeptide; PSA-ACT, prostate-specific antigen complexed to $\alpha 1$-antichymotrypsin; Chk2, serine/threonine-protein kinase Chk2; C4a, complement component C4a; C8, complement C8; ApoA2, apolipoprotein A-2; ApoH, apolipoprotein-H; IL-4, interleukin-4; G-CSF, granulocyte-colonystimulating factor; IL-2, interleukin-2; IFN- $\gamma$, interferon-gamma; PDGF, platelet-derived growth factor; NCAM, neural cell adhesion molecule; sRAGE, soluble receptor for advanced glycation end products; ICAM, intercellular adhesion molecule; NAP2, nucleosome assembly protein 2.

TABLE 3 | Summary of the significant findings of studies examining plasma protein markers of PET amyloid.

\begin{tabular}{|c|c|c|c|}
\hline Protein(s) & Outcome variable (subjects) & Analytical platform & Study \\
\hline ApoE, C3, albumin, plasminogen, haptoglobin and IgG C chain region & PiB PET amyloid (non-demented elderly) & 2DGE LC-MS/MS & $(137)$ \\
\hline $\begin{array}{l}\text { C-peptide, fibrinogen, A1AT, PPY, C3, vitronectin, cortisol, AXL receptor } \\
\text { kinase, IL-3, IL-13, MMP9, ApoE, and IgE (this panel of proteins combined } \\
\text { with covariates predicts amyloid positive subjects with } 92 \text { and } 55 \% \\
\text { sensitivity and specificity, respectively) }\end{array}$ & $\begin{array}{l}\text { PiB PET amyloid (AD, MCl, and non- } \\
\text { demented elderly) }\end{array}$ & $\begin{array}{l}\text { Luminex xMAP } \\
\text { (Myriad RBM) }\end{array}$ & $(138)$ \\
\hline $\begin{array}{l}\text { A2M, CFHR1, and FGG. (FGG in combination with age predicts NAB with } \\
59 \text { and } 78 \% \text { sensitivity and specificity, respectively) }\end{array}$ & $\begin{array}{l}\text { PiB PET amyloid (AD, MCl, and non- } \\
\text { demented elderly) }\end{array}$ & TMT LC-MS/MS & (140) \\
\hline $\begin{array}{l}\text { IL-6R, ApoE, and clusterin (in combination with clinical measures: trails B, } \\
\text { AVLT, MMSE, education, APOE genotype and mean hippocampal volume } \\
\text { predicts NAB with } 79 \text { and } 83 \% \text { sensitivity and specificity) }\end{array}$ & CSF A $\beta$ and PiB PET amyloid (MCI) & $\begin{array}{l}\text { Luminex XMAP } \\
\text { (Myriad RBM) }\end{array}$ & (125) \\
\hline PPY and $\operatorname{lgM}^{*}$ & $\begin{array}{l}\text { PiB PET amyloid (AD, MCl, and non- } \\
\text { demented elderly, }{ }^{*} \text { non-demented elderly } \\
\text { only) }\end{array}$ & SOMAscan & $(142)$ \\
\hline
\end{tabular}

ApoE, apolipoprotein E; C3, complement C3; A1AT, alpha 1 antitrypsin; PPY, pancreatic polypeptide; IL-3, interleukin-3; IL-13, interleukin-13; MMP9, matrix metalloproteinase-9 total; ApoE, apolipoprotein E; IgE, immunoglobulin E; CKCL-13, chemokine ligand 13; IL-17, interleukin-17; IgM-1, immunoglobulin M; VCAM-1, vascular cell adhesion protein; A2M, alpha 2 macroglobulin; CFHR1, CFH-related protein 1; FGG, fibrinogen gamma chain; NAB, neocortical amyloid burden.

*non demented elderly only. 
dependent on its concentration relative to $\mathrm{A} \beta$. Clusterin is implicated in $A \beta$ aggregation and clearance (146-151) and at high concentrations, clusterin binds $A \beta$, thus, preventing its aggregation. Yet when $A \beta$ levels are high, clusterin instead is incorporated with amyloid in insoluble aggregates (148). Furthermore, clusterin possesses neurotoxic properties, as demonstrated by its involvement in non-canonical wnt signaling (the wnt-PCP-JNK pathway), which mediates $A \beta$ toxicity (152). It could, therefore, be postulated that clusterin is playing different roles in these studies that demonstrate opposing relationships of plasma clusterin with brain atrophy. Nonetheless, these studies add further evidence for the role of clusterin in AD pathology. It is also worth noting that evidence for clusterin being implicated in $\mathrm{AD}$ pathology has also been provided on the genetic level, with an association of the variant rs11136000 in the clusterin gene with $\operatorname{AD}$ risk $(153,154)$, increased rates of cognitive decline at the pre-symptomatic stages of the disease (155) and brain volume and structure (volumetric expansion and lateral ventricle surface morphology) in AD, MCI, and elderly control subjects (156).

To date, clusterin is likely to be the most promising potential biomarker of $\mathrm{AD}$-related phenotypes that we have identified in our studies, as supported by an association on the proteomic level with both clinical and neuroimaging measures of AD pathology, on the genetic level with $\mathrm{AD}$ risk and on a mechanistic level with amyloid function and processing.

Following the identification of clusterin using a dual endophenotype-based approach founded upon both brain atrophy and cognitive decline measures, we sought to extend this approach further to find biomarkers of these endophenotypes using different proteomic methods, which may be more sensitive for detection of alternative groups of proteins. One such study was reported by Sattlecker et al. who utilized the SOMAscan technology for plasma protein biomarker discovery in a cohort of $\mathrm{AD}$, MCI, and controls. The strongest findings of this study included an association of clusterin with cognitive decline, replicating the findings of Thambisetty et al. (128), along with an association of fetuin B and pancreatic polypeptide with brain atrophy, and an association of pancreatic polypeptide and PSA-ACT with a diagnosis of AD (134).

In addition to hypothesis generating discovery approaches, targeted hypothesis-driven approaches have also been successful in identifying potential biomarkers of brain atrophy and cognitive decline. For example, the apolipoprotein family is widely implicated in neurodegeneration $(157,158)$ and in a targeted study, Song et al. showed a negative correlation of plasma clusterin and ApoE with gray matter volume and an association of ApoA1, ApoA2, ApoH, and the ApoB/ApoA1 ratio with risk of cognitive decline in cognitively normal individuals (130). As these proteins are associated with pathology-related outcomes at the preclinical stage of disease, this would suggest that the apolipoproteins may be markers in an early phase of the disease pathogenesis. More recently, Teng et al. also showed an association of plasma ApoE levels with hippocampal volume in a cohort of $\mathrm{AD}, \mathrm{MCI}$, and control included in the Alzheimer's disease neuroimaging initiative (ADNI) cohort (135).

We have also taken a targeted approach to examine the biomarker potential of inflammatory proteins (132), given the evidence for an inflammatory component in $\mathrm{AD}$ pathology $(159,160)$. We observed five proteins that were associated with brain atrophy measures (IL-1ra, IL-6, IL-10, TNF- $\alpha$, and IL-13) and six proteins that were associated with rate of cognitive decline in AD (IL-4, IL-10, G-CSF, IL-2, IFN- $\gamma$, and PDGF) (132). Of note was the association of IL-10 with both brain atrophy and rate of cognitive decline, adding further confidence to the finding of its association with AD-related endophenotypes (132). Toledo et al. also published findings of inflammatory proteins (macrophage inflammatory protein 1 alpha, chromogranin A) along with proteins implicated in the stress response (cortisol) and insulin response (insulinlike growth factor binding protein 2) as markers of brain atrophy (133).

Following the identification of various plasma proteins related to $\mathrm{AD}$ and proxy measures of disease activity (neuroimaging measured of brain atrophy and clinical measures of cognitive decline), we next sought to validate the most promising and disease-relevant protein markers. To do this, we used multiplex bead assays to measure candidate proteins in a larger $(N>1000)$ cohort of $\mathrm{AD} / \mathrm{MCI} /$ control participants (124). Interestingly, we found that different sets of proteins were associated with brain atrophy in MCI compared to $\mathrm{AD}$, indicating that these markers are disease-phase specific, and the strongest associations with brain atrophy were observed for clusterin in the MCI group and ApoE in the AD group (124). Furthermore, we identified three proteins NCAM, sRAGE, and ICAM as being associated with rate of cognitive decline and we, therefore, hypothesized that these markers may be predictive of conversion from MCI to AD. When we tested this, we found that there were a panel of 10 proteins (transthyretin, clusterin, cystatin C, A1AcidG, ICAM1, complement component C4, PEDF, A1AT, RANTES, and ApoC3) along with $A P O E$ genotype, which were able to predict MCI conversion to $\mathrm{AD}$ with $87 \%$ accuracy, $85 \%$ sensitivity, and $88 \%$ specificity, as described earlier (124).

\section{Blood-Based Biomarkers of Brain Amyloid Burden}

Blood-based biomarkers of neocortical $\mathrm{A} \beta$ (extracellular $\beta$-amyloid) burden (NAB) as measured by PET brain imaging have also been sought (Table 3). These studies have used the Australian Imaging, Biomarker and Lifestyle Flagship Study of Ageing (AIBL) (161), the ADNI ${ }^{4}$, and the BLSA (144) for the purpose of finding plasma proteomic markers of brain amyloid burden.

The first study we carried out used the BLSA study to discover plasma proteins that were associated with NAB in non-demented elderly individuals (137). Using a 2DGE-MS/MS-based approach, this study identified six proteins (ApoE, Complement C3, Albumin, Plasminogen, Haptoglobin and IgG $\mathrm{C}$ chain region) that discriminated "high" from "low" PiB PET brain amyloid burden subjects in discovery-based studies, and a further association of ApoE with amyloid burden in the medial temporal lobe in an independent validation study (137).

${ }^{4}$ www.adni-info.org 
Following this, we carried out a separate study to examine the association of plasma proteins with $\mathrm{NAB}$ in $\mathrm{AD}, \mathrm{MCI}$, and control subjects included in the $\mathrm{ADNI}^{5}$ (138). Plasma proteins were measured by the Myriad Rules-Based Medicine (RBM) panel using commercially available multiplexed luminex assays. This work identified 13 plasma proteins (c-peptide, fibrinogen, A1AT, pancreatic polypeptide, complement C3, vitronectin, cortisol, AXL receptor kinase, IL-3, IL-13, matrix metalloproteinase-9 total, ApoE, and IgE), which in combination with covariates were able to discriminate $\mathrm{PiB}$-positive from $\mathrm{PiB}$-negative individuals with 92 and 55\% sensitivity and specificity, respectively (138).

Shortly after this, Burnham et al. published a study that again utilized the RBM panel for identifying plasma proteins predictive of $\mathrm{NAB}$ in an $\mathrm{AD}, \mathrm{MCI}$, and control-based population; however, this study utilized the AIBL study for discovery, followed by validation of potential biomarkers of NAB in the ADNI (139). In summary, Burnham et al. identified six plasma proteins $\left(A \beta_{42}\right.$, chemokine ligand 13, IL-17, IgM-1, pancreatic polypeptide and VCAM-1) that contributed to a biomarker signature that was able to predict NAB with 79 and $76 \%$ sensitivity and specificity in the ADNI-based validation cohort (139).

More recently, a study carried out in an ADNI-based MCI cohort revealed that plasma IL-6 receptor, clusterin, and ApoE levels coupled with a number of clinical and demographic measures, $A P O E$ genotype and mean hippocampal volume, achieved 79 and $83 \%$ sensitivity and specificity for prediction of NAB (125). Hwang et al. also reported an association of reduced plasma BDNF levels with increased regional measures of NAB in an ADNI cohort (141).

We also recently reported the results of an LC-MS/MS-based approach for the discovery of plasma protein biomarkers of NAB in $\mathrm{AD}, \mathrm{MCI}$, and healthy controls enrolled in the AIBL study (140). Using this approach, a number of plasma proteins were shown to be significantly associated with NAB, including A2M, $\mathrm{CFH}$-related protein 1 , and $\gamma$-fibrinogen. Moreover, the association of $\gamma$-fibrinogen in combination with age was found to predict NAB with 59 and $78 \%$ sensitivity and specificity, respectively (140).

Although the exact protein biomarker panels identified by these studies for prediction of NAB differs between the studies, it is of note that there are some commonalities in the proteins included in these biomarker panels, including ApoE $(125,137$, 138), complement C3 (137, 138), and pancreatic polypeptide $(138,139)$. A recent study, therefore, sought to replicate these findings in an independent cohort of $\mathrm{AD}, \mathrm{MCI}$, and control subjects in the AIBL study (142). This work replicated an association of two proteins with NAB; pancreatic polypeptide across the cohort of AD, MCI, and cognitively healthy elderly, and IgM in the cognitively healthy elderly group, while the association of the other protein candidates with NAB was not replicated (142). This lack of replication between studies is disappointing; however, it is quite possible that this could be in part due to technical platform differences, as the discovery studies used both MS $(137,140)$ and immunocapture-based approaches $(125,138,139,141)$, while

${ }^{5}$ adni.loni.ucla.edu replication was sought using the SOMAscan platform (142). As mentioned earlier, platform and assay differences may provide differing quantitative proteomic results, given that there are key differences in the nature of the protein being measured by these techniques. MS approaches measure denatured protein in a peptide-specific manner, while immunocapture-based assays use antibodies for epitope-specific native protein measures. The SOMAscan platform also measures native protein, but by binding of an aptamer to a tertiary structure-specific epitope. Therefore, differences in the region and confirmation of the protein target being measured by these different techniques may result in varying quantitative results.

These various studies utilizing an $\mathrm{AD}$ pathology endophenotype-based approach for biomarker discovery show promise in identifying biomarkers reflective of core $\mathrm{AD}$ pathology and disease activity. However, it is important to note that there are some issues surrounding the approach of predicating bloodbased biomarker discovery on PET amyloid measures. First, $\mathrm{PiB}$ PET detects insoluble fibrillary but not insoluble oligomeric $\mathrm{A} \beta$, which are known to possess neurotoxic and synaptotoxic properties (162). Therefore, blood-based biomarkers of PiB PET amyloid may not be the most relevant markers of brain amyloid pathology. Second, it is possible that the relationship of plasma proteins with $\mathrm{PiB}$ PET amyloid measures could be specific to the technical aspects of the PET imaging technique used. For example, variability in the amyloid measure could be introduced by the use of alternative radiotracers or alternative methods of PET data analysis.

Therefore, in order to assess the reproducibility and robustness of plasma proteins biomarkers of amyloid (as indicated by $\mathrm{PiB}$ PET), it will be essential to perform replication and validation studies examining their association with brain amyloid burden (1) in larger independent cohorts, (2) using orthogonal technical platforms for biomarker quantification, and (3) using alternative measures indicative of amyloid (for example, alternative PET amyloid radiotracers and CSF $A \beta$ ).

\section{Other Potential Endophenotype Approaches}

While endophenotype-based designs founded upon rates of cognitive decline, brain atrophy, and brain amyloid burden show promise, there are further measures of $\mathrm{AD}$ and other aspects of core $\mathrm{AD}$ neuropathology that warrant investigation as potential endophenotypes for biomarker discovery. FDG-PET measures cerebral metabolic glucose utilization rate and serves as an indicator of synaptic activity, neuronal function, and neuronal metabolic activity (163). FDG-PET has been reported to have an average diagnostic accuracy of 93\% (96\% sensitivity and 90\% specificity) for differentiating $\mathrm{AD}$ from cognitively healthy elderly subjects (164), and can discriminate between different dementiatypes with around 94\% accuracy (165). Using FDG-PET as an endophenotype of pathology for blood-based biomarker discovery could, therefore, aid in the development of biomarkers relating to synaptic and neuronal function, and the prodromal stage of disease, given that hypometabolism is known to occur in amnestic MCI $(165,166)$. Moreover, glucose metabolism 
is thought to be more closely associated with certain memory, language, and visuospatial clinical variants of $\mathrm{AD}$ than measures of $\mathrm{A} \beta$ deposition and so plasma protein biomarkers of FDG-PET cerebral glucose metabolism could be of utility in detecting these clinical aspects of the disease (167).

With the development of tau imaging comes the opportunity to investigate blood-based biomarkers related specifically to brain tau pathology, which could obviously be of potential utility beyond $\mathrm{AD}$ and for tauopathies such as fronto-temporal dementia. The development of tau imaging has been challenging due to the deposition of tau protein being intracellular, which impacts upon radiotracer binding and image contrast (168). However, current research to develop various tau brain imaging tracers is underway, including the tracers 18F-THK523, [F-18]-T807, and [F-18]-T808 (169-171). PET imaging of tau could, therefore, provide another endophenotype parameter for the design of studies that seek to uncover peripheral proteomic biomarkers relating specifically to tau pathology in the brain.

Moreover, other types of biomarkers detectable in the blood show promise as potential markers of $\mathrm{AD}$, including, for example, metabolomic (172-175) and transcriptomic-based markers (176, 177). Further research to examine how these markers may be related to pathology endophenotypes and the potential of combining these markers as a multimodal signature of $\mathrm{AD}$ pathology will be important.

\section{CONCLUSION}

Much research has sought blood-based proteomic biomarkers that may have diagnostic utility in discriminating $\mathrm{AD}$ cases from control, with limited success in identifying a reproducible signature of diagnostic or trials utility.

An alternative approach, which we have increasingly employed is using surrogates for disease activity - endophenotypes - such as cerebral atrophy imaging or molecular markers of amyloid pathology and rate of decline. Such an approach yields different but overlapping panels of markers. It is, therefore, possible that

\section{REFERENCES}

1. Prince M, Bryce R, Albanese E, Wimo A, Ribeiro W, Ferri CP. The global prevalence of dementia: a systematic review and metaanalysis. Alzheimers Dement (2013) 9:63-75.e2. doi:10.1016/j.jalz.2012.11.007

2. Wimo A, Prince M. World Alzheimer Report 2010: The Global Economic Impact of Dementia. London : Alzheimer's Disease International (2010).

3. Francis PT, Palmer AM, Snape M, Wilcock GK. The cholinergic hypothesis of Alzheimer's disease: a review of progress. J Neurol Neurosurg Psychiatry (1999) 66:137-47. doi:10.1136/jnnp.66.2.137

4. Villemagne VL, Pike KE, Chetelat G, Ellis KA, Mulligan RS, Bourgeat P, et al. Longitudinal assessment of Abeta and cognition in aging and Alzheimer disease. Ann Neurol (2011) 69:181-92. doi:10.1002/ana.22248

5. Johnson KA, Fox NC, Sperling RA, Klunk WE. Brain imaging in Alzheimer disease. Cold Spring Harb Perspect Med (2012) 2:a006213. doi:10.1101/ cshperspect.a006213

6. Kang JH, Korecka M, Toledo JB, Trojanowski JQ, Shaw LM. Clinical utility and analytical challenges in measurement of cerebrospinal fluid amyloid-beta(1-42) and tau proteins as Alzheimer disease biomarkers. Clin Chem (2013) 59:903-16. doi:10.1373/clinchem.2013.202937

7. Teunissen CE, Verwey NA, Kester MI, Van Uffelen K, Blankenstein MA. Standardization of assay procedures for analysis of the CSF biomarkers such markers predicated on pathological processes might be more reproducible and ultimately of more utility in diagnostic, prognostic, predictive, and other utilities especially in the context of clinical trials.

However, it seems intrinsically unlikely to us that a bloodbased biomarker would replace relatively specific and reliable markers such as molecular markers in CSF or PET imaging markers that are more proximal to the disease state. Rather, we predict that blood-based biomarkers might be less specific but possibly more sensitive and certainly more readily conducted repeatedly in the context of large-scale, community-based studies and where repeated measures to track change is required. This then raises the prospect of what might be termed the biomarker funnel, a series of tests and investigations starting with the minimally invasive, highly sensitive, poorly specific marker set leading toward a technologically demanding or invasive test that is highly specific. This would be a blood test triage or selection process for CSF or PET tests in effect. Such a funnel is commonplace in medicine - fasting glucose before a glucose tolerance test, mammography before biopsy are examples, but there are many others. A biomarker funnel with blood-based markers as an early step toward a pathological diagnosis in life would be a very substantial step forward and maybe an essential step before clinical trials can be both effective and achievable.

\section{AUTHOR CONTRIBUTIONS}

$\mathrm{AB}, \mathrm{SW}$, and SL all contributed to the design of the review and interpretation of the studies included within it. AB, SW, and SL all contributed to the drafting and revision of the content and provided final approval of this version to be published.

\section{ACKNOWLEDGMENTS}

Research in the authors' laboratories is supported by Alzheimer's Research UK, Alzheimer's Society, MRC, NIHR, Parkinson's UK, Wellcome trust, and the EU.

amyloid beta((1-42)), tau, and phosphorylated tau in Alzheimer's disease: report of an international workshop. Int J Alzheimers Dis (2010) 35:271-8. doi:10.4061/2010/635053

8. Jack CR Jr, Knopman DS, Jagust WJ, Petersen RC, Weiner MW, Aisen PS, et al. Tracking pathophysiological processes in Alzheimer's disease: an updated hypothetical model of dynamic biomarkers. Lancet Neurol (2013) 12:207-16. doi:10.1016/S1474-4422(12)70291-0

9. Toledo JB, Bjerke M, Da X, Landau SM, Foster NL, Jagust W, et al. Nonlinear association between cerebrospinal fluid and florbetapir F-18 beta-amyloid measures across the spectrum of Alzheimer disease. JAMA Neurol (2015) 72:571-81. doi:10.1001/jamaneurol.2014.4829

10. Anderson NL, Anderson NG. The human plasma proteome. Mol Cell Proteomics (2002) 1:845-67. doi:10.1074/mcp.R200007-MCP200

11. Montagne A, Barnes SR, Sweeney MD, Halliday MR, Sagare AP, Zhao Z, et al. Blood-brain barrier breakdown in the aging human hippocampus. Neuron (2015) 85:296-302. doi:10.1016/j.neuron.2014.12.032

12. Lewczuk P, Esselmann H, Bibl M, Paul S, Svitek J, Miertschischk J, et al. Electrophoretic separation of amyloid beta peptides in plasma. Electrophoresis (2004) 25:3336-43. doi:10.1002/elps.200406068

13. Westbrook JA, Noirel J, Brown JE, Wright PC, Evans CA. Quantitation with chemical tagging reagents in biomarker studies. Proteomics Clin Appl (2015) 9:295-300. doi:10.1002/prca.201400120 
14. Tirumalai RS, Chan KC, Prieto DA, Issaq HJ, Conrads TP, Veenstra TD. Characterization of the low molecular weight human serum proteome. Mol Cell Proteomics (2003) 2:1096-103. doi:10.1074/mcp.M300031-MCP200

15. Mostovenko EH, Rattke C, Deelder J, Van Veelen PA, Palmblad M. Comparison of peptide and protein fractionation methods in proteomics. EuPA Open Proteom (2013) 1:30-7. doi:10.1016/j.euprot.2013.09.001

16. Liao Q, Zhao L, Chen X, Deng Y, Ding Y. Serum proteome analysis for profiling protein markers associated with carcinogenesis and lymph node metastasis in nasopharyngeal carcinoma. Clin Exp Metastasis (2008) 25:465-76. doi:10.1007/s10585-008-9152-8

17. Kaur P, Reis MD, Couchman GR, Forjuoh SN, Greene JF, Asea A. Serpine 1 links obesity and diabetes: a pilot study. J Proteomics Bioinform (2010) 3:191-9. doi:10.4172/jpb.1000139

18. Tang HY, Beer LA, Barnhart KT, Speicher DW. Rapid verification of candidate serological biomarkers using gel-based, label-free multiple reaction monitoring. J Proteome Res (2011) 10:4005-17. doi:10.1021/pr2002098

19. Mulder C, Verwey NA, van der Flier WM, Bouwman FH, Kok A, van Elk EJ, et al. Amyloid-beta(1-42), total tau, and phosphorylated tau as cerebrospinal fluid biomarkers for the diagnosis of Alzheimer disease. Clin Chem (2010) 56:248-53. doi:10.1373/clinchem.2009.130518

20. Murphy MP, LeVine H. Alzheimer's disease and the amyloid-beta peptide. J Alzheimers Dis (2010) 19:311-23. doi:10.3233/JAD-2010-1221

21. Masters CL, Simms G, Weinman NA, Multhaup G, McDonald BL, Beyreuther K. Amyloid plaque core protein in Alzheimer disease and Down syndrome. Proc Natl Acad Sci U S A (1985) 82:4245-9. doi:10.1073/pnas.82.12.4245

22. Wang J, Dickson DW, Trojanowski JQ, Lee VM. The levels of soluble versus insoluble brain Abeta distinguish Alzheimer's disease from normal and pathologic aging. Exp Neurol (1999) 158:328-37. doi:10.1006/exnr.1999.7085

23. Song F, Poljak A, Valenzuela M, Mayeux R, Smythe GA, Sachdev PS. Metaanalysis of plasma amyloid-beta levels in Alzheimer's disease. J Alzheimers Dis (2011) 26:365-75. doi:10.3233/JAD-2011-101977

24. Koyama A, Okereke OI, Yang T, Blacker D, Selkoe DJ, Grodstein F. Plasma amyloid-beta as a predictor of dementia and cognitive decline: a systematic review and meta-analysis. Arch Neurol (2012) 69:824-31. doi:10.1001/ archneurol.2011.1841

25. Lui JK, Laws SM, Li QX, Villemagne VL, Ames D, Brown B, et al. Plasma amyloid-beta as a biomarker in Alzheimer's disease: the AIBL study of aging. J Alzheimers Dis (2010) 20:1233-42. doi:10.3233/JAD-2010-090249

26. Abdullah L, Paris D, Luis C, Quadros A, Parrish J, Valdes L, et al. The influence of diagnosis, intra- and inter-person variability on serum and plasma Abeta levels. Neurosci Lett (2007) 428:53-8. doi:10.1016/j. neulet.2007.09.058

27. Locascio JJ, Fukumoto H, Yap L, Bottiglieri T, Growdon JH, Hyman BT, et al. Plasma amyloid beta-protein and C-reactive protein in relation to the rate of progression of Alzheimer disease. Arch Neurol (2008) 65:776-85. doi:10.1001/archneur.65.6.776

28. Rembach A, Faux NG, Watt AD, Pertile KK, Rumble RL, Trounson BO, et al. Changes in plasma amyloid beta in a longitudinal study of aging and Alzheimer's disease. Alzheimers Dement (2014) 10:53-61. doi:10.1016/j. jalz.2012.12.006

29. Fei M, Jianghua W, Rujuan M, Wei Z, Qian W. The relationship of plasma Abeta levels to dementia in aging individuals with mild cognitive impairment. J Neurol Sci (2011) 305:92-6. doi:10.1016/j.jns.2011.03.005

30. Blasko I, Jellinger K, Kemmler G, Krampla W, Jungwirth S, Wichart I, et al. Conversion from cognitive health to mild cognitive impairment and Alzheimer's disease: prediction by plasma amyloid beta 42, medial temporal lobe atrophy and homocysteine. Neurobiol Aging (2008) 29:1-11. doi:10.1016/j.neurobiolaging.2006.09.002

31. Mayeux R, Honig LS, Tang MX, Manly J, Stern Y, Schupf N, et al. Plasma A[beta]40 and A[beta]42 and Alzheimer's disease: relation to age, mortality, and risk. Neurology (2003) 61:1185-90. doi:10.1212/01. WNL.0000091890.32140.8F

32. Pomara N, Willoughby LM, Sidtis JJ, Mehta PD. Selective reductions in plasma Abeta 1-42 in healthy elderly subjects during longitudinal follow-up: a preliminary report. Am J Geriatr Psychiatry (2005) 13:914-7. doi:10.1097/00019442-200510000-00012

33. Wang T, Xiao S, Liu Y, Lin Z, Su N, Li X, et al. The efficacy of plasma biomarkers in early diagnosis of Alzheimer's disease. Int J Geriatr Psychiatry (2014) 29:713-9. doi:10.1002/gps.4053
34. Buerger K, Frisoni G, Uspenskaya O, Ewers M, Zetterberg H, Geroldi C, et al. Validation of Alzheimer's disease CSF and plasma biological markers: the multicentre reliability study of the pilot European Alzheimer's disease neuroimaging initiative (E-ADNI). Exp Gerontol (2009) 44:579-85. doi:10.1016/j. exger.2009.06.003

35. Chouraki V, Beiser A, Younkin L, Preis SR, Weinstein G, Hansson O, et al. Plasma amyloid-beta and risk of Alzheimer's disease in the Framingham Heart Study. Alzheimers Dement (2015) 11:249-57. doi:10.1016/j.jalz.2014.07.001

36. Graff-Radford NR, Crook JE, Lucas J, Boeve BF, Knopman DS, Ivnik RJ, et al. Association of low plasma Abeta42/Abeta40 ratios with increased imminent risk for mild cognitive impairment and Alzheimer disease. Arch Neurol (2007) 64:354-62. doi:10.1001/archneur.64.3.354

37. van Oijen M, Hofman A, Soares HD, Koudstaal PJ, Breteler MM. Plasma $\operatorname{Abeta}(1-40)$ and $\operatorname{Abeta}(1-42)$ and the risk of dementia: a prospective case-cohort study. Lancet Neurol (2006) 5:655-60. doi:10.1016/ S1474-4422(06)70501-4

38. Ghersi-Egea JF, Gorevic PD, Ghiso J, Frangione B, Patlak CS, Fenstermacher JD. Fate of cerebrospinal fluid-borne amyloid beta-peptide: rapid clearance into blood and appreciable accumulation by cerebral arteries. J Neurochem (1996) 67:880-3. doi:10.1046/j.1471-4159.1996.67020880.x

39. Motter R, Vigo-Pelfrey C, Kholodenko D, Barbour R, Johnson-Wood K, Galasko D, et al. Reduction of beta-amyloid peptide42 in the cerebrospinal fluid of patients with Alzheimer's disease. Ann Neurol (1995) 38:643-8. doi:10.1002/ana.410380413

40. Mehta PD, Pirttila T, Patrick BA, Barshatzky M, Mehta SP. Amyloid beta protein 1-40 and 1-42 levels in matched cerebrospinal fluid and plasma from patients with Alzheimer disease. Neurosci Lett (2001) 304:102-6. doi:10.1016/S0304-3940(01)01754-2

41. Le Bastard N, Aerts L, Leurs J, Blomme W, De Deyn PP, Engelborghs S. No correlation between time-linked plasma and CSF Abeta levels. Neurochem Int (2009) 55:820-5. doi:10.1016/j.neuint.2009.08.006

42. Bateman RJ, Xiong C, Benzinger TL, Fagan AM, Goate A, Fox NC, et al. Clinical and biomarker changes in dominantly inherited Alzheimer's disease. N Engl J Med (2012) 367:795-804. doi:10.1056/NEJMoa1202753

43. Thomas T, Thomas G, McLendon C, Sutton T, Mullan M. Beta-amyloidmediated vasoactivity and vascular endothelial damage. Nature (1996) 380:168-71. doi:10.1038/380168a0

44. Petrovitch H, Ross GW, Steinhorn SC, Abbott RD, Markesbery W, Davis $\mathrm{D}$, et al. $\mathrm{AD}$ lesions and infarcts in demented and non-demented JapaneseAmerican men. Ann Neurol (2005) 57:98-103. doi:10.1002/ana.20318

45. Freeman SH, Raju S, Hyman BT, Frosch MP, Irizarry MC. Plasma Abeta levels do not reflect brain Abeta levels. J Neuropathol Exp Neurol (2007) 66:264-71. doi:10.1097/NEN.0b013e31803d3ae4

46. Devanand DP, Schupf N, Stern Y, Parsey R, Pelton GH, Mehta P, et al. Plasma Abeta and PET PiB binding are inversely related in mild cognitive impairment. Neurology (2011) 77:125-31. doi:10.1212/WNL.0b013e318224afb7

47. Tzen KY, Yang SY, Chen TF, Cheng TW, Horng HE, Wen HP, et al. Plasma Abeta but not tau is related to brain PiB retention in early Alzheimer's disease. ACS Chem Neurosci (2014) 5:830-6. doi:10.1021/cn500101j

48. Kaneko N, Nakamura A, Washimi Y, Kato T, Sakurai T, Arahata Y, et al. Novel plasma biomarker surrogating cerebral amyloid deposition. Proc Jpn Acad Ser B Phys Biol Sci (2014) 90:353-64. doi:10.2183/pjab.90.353

49. Huang Y, Potter R, Sigurdson W, Kasten T, Connors R, Morris JC, et al. Beta-amyloid dynamics in human plasma. Arch Neurol (2012) 69:1591-7. doi:10.1001/archneurol.2012.18107

50. Kuo YM, Emmerling MR, Lampert HC, Hempelman SR, Kokjohn TA, Woods AS, et al. High levels of circulating Abeta42 are sequestered by plasma proteins in Alzheimer's disease. Biochem Biophys Res Commun (1999) 257:787-91. doi:10.1006/bbrc.1999.0552

51. Sotolongo-Grau O, Pesini P, Valero S, Lafuente A, Buendia M, Perez-Grijalba $\mathrm{V}$, et al. Association between cell-bound blood amyloid-beta(1-40) levels and hippocampus volume. Alzheimers Res Ther (2014) 6:56. doi:10.1186/ s13195-014-0056-3

52. Chiu MJ, Yang SY, Chen TF, Chieh JJ, Huang TZ, Yip PK, et al. New assay for old markers-plasma beta amyloid of mild cognitive impairment and Alzheimer's disease. Curr Alzheimer Res (2012) 9:1142-8. doi:10.2174/156720512804142967

53. Henriksen K, Wang Y, Sorensen MG, Barascuk N, Suhy J, Pedersen JT, et al. An enzyme-generated fragment of tau measured in serum shows an inverse 
correlation to cognitive function. PLoS One (2013) 8:e64990. doi:10.1371/ journal.pone.0064990

54. Henriksen K, Byrjalsen I, Christiansen C, Karsdal MA. Relationship between serum levels of tau fragments and clinical progression of Alzheimer's disease. J Alzheimers Dis (2015) 43:1331-41. doi:10.3233/JAD-140984

55. Zetterberg H, Wilson D, Andreasson U, Minthon L, Blennow K, Randall J, et al. Plasma tau levels in Alzheimer's disease. Alzheimers Res Ther (2013) 5:9. doi:10.1186/alzrt163

56. Rissin DM, Kan CW, Campbell TG, Howes SC, Fournier DR, Song L, et al. Single-molecule enzyme-linked immunosorbent assay detects serum proteins at subfemtomolar concentrations. Nat Biotechnol (2010) 28:595-9. doi:10.1038/nbt.1641

57. Chiu MJ, Chen YF, Chen TF, Yang SY, Yang FP, Tseng TW, et al. Plasma tau as a window to the brain-negative associations with brain volume and memory function in mild cognitive impairment and early Alzheimer's disease. Hum Brain Mapp (2014) 35:3132-42. doi:10.1002/hbm.22390

58. Zipser BD, Johanson CE, Gonzalez L, Berzin TM, Tavares R, Hulette $\mathrm{CM}$, et al. Microvascular injury and blood-brain barrier leakage in Alzheimer's disease. Neurobiol Aging (2007) 28:977-86. doi:10.1016/j. neurobiolaging.2006.05.016

59. Bush AI, Whyte S, Thomas LD, Williamson TG, Van Tiggelen CJ, Currie J, et al. An abnormality of plasma amyloid protein precursor in Alzheimer's disease. Ann Neurol (1992) 32:57-65. doi:10.1002/ana.410320110

60. Kennard ML, Feldman H, Yamada T, Jefferies WA. Serum levels of the iron binding protein p97 are elevated in Alzheimer's disease. Nat Med (1996) 2:1230-5. doi:10.1038/nm1196-1230

61. Lombardi VR, Cacabelos R. 19/20 kDa low molecular weight serum protein pattern: a novel potential biochemical prognostic marker for different types of dementia. Neurosci Lett (1999) 260:61-4. doi:10.1016/ S0304-3940(98)00960-4

62. Diamandis EP, Yousef GM, Petraki C, Soosaipillai AR. Human kallikrein 6 as a biomarker of Alzheimer's disease. Clin Biochem (2000) 33:663-7. doi:10.1016/S0009-9120(00)00185-5

63. Kalman J, Marki-Zay J, Juhasz A, Santha A, Dux L, Janka Z. Serum and cerebrospinal fluid cystatin C levels in vascular and Alzheimer's dementia. Acta Neurol Scand (2000) 101:279-82. doi:10.1034/j.1600-0404.2000.09011.x

64. Ueno I, Sakai T, Yamaoka M, Yoshida R, Tsugita A. Analysis of blood plasma proteins in patients with Alzheimer's disease by two-dimensional electrophoresis, sequence homology and immunodetection. Electrophoresis (2000) 21:1832-45. doi:10.1002/ (SICI)1522-2683(20000501)21:9<1832::AID-ELPS1832>3.0.CO;2-7

65. Licastro F, Pedrini S, Davis LJ, Caputo L, Tagliabue J, Savorani G, et al. Alpha-1-antichymotrypsin and oxidative stress in the peripheral blood from patients with probable Alzheimer disease: a short-term longitudinal study. Alzheimer Dis Assoc Disord (2001) 15:51-5. doi:10.1097/00002093-200101000-00007

66. Schmidt R, Schmidt H, Curb JD, Masaki K, White LR, Launer LJ. Early inflammation and dementia: a 25-year follow-up of the Honolulu-Asia Aging Study. Ann Neurol (2002) 52:168-74. doi:10.1002/ana.10265

67. Mocali A, Cedrola S, Della Malva N, Bontempelli M, Mitidieri VA, Bavazzano A, et al. Increased plasma levels of soluble CD40, together with the decrease of TGF beta 1, as possible differential markers of Alzheimer disease. Exp Gerontol (2004) 39:1555-61. doi:10.1016/j.exger.2004.07.007

68. Zhang R, Barker L, Pinchev D, Marshall J, Rasamoelisolo M, Smith C, et al. Mining biomarkers in human sera using proteomic tools. Proteomics (2004) 4:244-56. doi:10.1002/pmic.200300495

69. van Oijen M, Witteman JC, Hofman A, Koudstaal PJ, Breteler MM. Fibrinogen is associated with an increased risk of Alzheimer disease and vascular dementia. Stroke (2005) 36:2637-41. doi:10.1161/01.STR.0000189721.31432.26

70. Liu HC, Hu CJ, Chang JG, Sung SM, Lee LS, Yuan RY, et al. Proteomic identification of lower apolipoprotein A-I in Alzheimer's disease. Dement Geriatr Cogn Disord (2006) 21:155-61. doi:10.1159/000090676

71. Guerreiro RJ, Santana I, Bras JM, Santiago B, Paiva A, Oliveira C. Peripheral inflammatory cytokines as biomarkers in Alzheimer's disease and mild cognitive impairment. Neurodegener Dis (2007) 4:406-12. doi:10.1159/000107700

72. Liao PC, Yu L, Kuo CC, Lin C, Kuo YM. Proteomics analysis of plasma for potential biomarkers in the diagnosis of Alzheimer's disease. Proteomics Clin Appl (2007) 1:506-12. doi:10.1002/prca.200600684
73. Ozturk C, Ozge A, Yalin OO, Yilmaz IA, Delialioglu N, Yildiz C, et al. The diagnostic role of serum inflammatory and soluble proteins on dementia subtypes: correlation with cognitive and functional decline. Behav Neurol (2007) 18:207-15. doi:10.1155/2007/432190

74. Guntert A, Campbell J, Saleem M, O’brien DP, Thompson AJ, Byers HL, et al. Plasma gelsolin is decreased and correlates with rate of decline in Alzheimer's disease. J Alzheimers Dis (2010) 21:585-96. doi:10.3233/JAD-2010-100279

75. Laske C, Stransky E, Hoffmann N, Maetzler W, Straten G, Eschweiler GW, et al. Macrophage colony-stimulating factor (M-CSF) in plasma and CSF of patients with mild cognitive impairment and Alzheimer's disease. Curr Alzheimer Res (2010) 7:409-14. doi:10.2174/156720510791383813

76. Mueller C, Zhou W, Vanmeter A, Heiby M, Magaki S, Ross MM, et al. The heme degradation pathway is a promising serum biomarker source for the early detection of Alzheimer's disease. J Alzheimers Dis (2010) 19:1081-91. doi:10.3233/JAD-2010-1303

77. Han SH, Jung ES, Sohn JH, Hong HJ, Hong HS, Kim JW, et al. Human serum transthyretin levels correlate inversely with Alzheimer's disease. J Alzheimers Dis (2011) 25:77-84. doi:10.3233/JAD-2011-102145

78. Ijsselstijn L, Dekker LJ, Stingl C, van der Weiden MM, Hofman A, Kros JM, et al. Serum levels of pregnancy zone protein are elevated in presymptomatic Alzheimer's disease. J Proteome Res (2011) 10:4902-10. doi:10.1021/ pr200270z

79. Teunissen CE, Veerhuis R, De Vente J, Verhey FR, Vreeling F, Van Boxtel MP, et al. Brain-specific fatty acid-binding protein is elevated in serum of patients with dementia-related diseases. Eur J Neurol (2011) 18:865-71. doi:10.1111/j.1468-1331.2010.03273.x

80. Henkel AW, Muller K, Lewczuk P, Muller T, Marcus K, Kornhuber J, et al. Multidimensional plasma protein separation technique for identification of potential Alzheimer's disease plasma biomarkers: a pilot study. J Neural Transm (2012) 119:779-88. doi:10.1007/s00702-012-0781-3

81. Wu G, Sankaranarayanan S, Wong J, Tugusheva K, Michener MS, Shi X, et al. Characterization of plasma beta-secretase (BACE1) activity and soluble amyloid precursor proteins as potential biomarkers for Alzheimer's disease. J Neurosci Res (2012) 90:2247-58. doi:10.1002/jnr.23122

82. Yang MH, Yang YH, Lu CY, Jong SB, Chen LJ, Lin YF, et al. Activitydependent neuroprotector homeobox protein: a candidate protein identified in serum as diagnostic biomarker for Alzheimer's disease. J Proteomics (2012) 75:3617-29. doi:10.1016/j.jprot.2012.04.017

83. Androsova LV, Mikhailova NM, Zozulia SA, Dupin AM, Rassadina GA, Lavrent'eva NV, et al. Inflammatory markers in Alzheimer's disease and vascular dementia. Zh Nevrol Psikhiatr Im S S Korsakova (2013) 113:49-53.

84. Gaiottino J, Norgren N, Dobson R, Topping J, Nissim A, Malaspina A, et al. Increased neurofilament light chain blood levels in neurodegenerative neurological diseases. PLoS One (2013) 8:e75091. doi:10.1371/journal. pone. 0075091

85. Gezen-Ak D, Dursun E, Hanagasi H, Bilgic B, Lohman E, Araz OS, et al. BDNF, TNFalpha, HSP90, CFH, and IL-10 serum levels in patients with early or late onset Alzheimer's disease or mild cognitive impairment. J Alzheimers Dis (2013) 37:185-95. doi:10.3233/JAD-130497

86. Johansson P, Aberg D, Johansson JO, Mattsson N, Hansson O, Ahren B, et al. Serum but not cerebrospinal fluid levels of insulin-like growth factor-I (IGF-I) and IGF-binding protein-3 (IGFBP-3) are increased in Alzheimer's disease. Psychoneuroendocrinology (2013) 38:1729-37. doi:10.1016/j. psyneuen.2013.02.006

87. Perneczky R, Guo LH, Kagerbauer SM, Werle L, Kurz A, Martin J, et al. Soluble amyloid precursor protein beta as blood-based biomarker of Alzheimer's disease. Transl Psychiatry (2013) 3:e227. doi:10.1038/tp.2013.11

88. Sun L, Tan MS, Hu N, Yu JT, Tan L. Exploring the value of plasma BIN1 as a potential biomarker for Alzheimer's disease. J Alzheimers Dis (2013) 37:291-5. doi:10.3233/JAD-130392

89. Shih YH, Tsai KJ, Lee CW, Shiesh SC, Chen WT, Pai MC, et al. Apolipoprotein C-III is an amyloid-beta-binding protein and an early marker for Alzheimer's disease. J Alzheimers Dis (2014) 41:855-65. doi:10.3233/JAD-140111

90. Hertze J, Nagga K, Minthon L, Hansson O. Changes in cerebrospinal fluid and blood plasma levels of IGF-II and its binding proteins in Alzheimer's disease: an observational study. BMC Neurol (2014) 14:64. doi:10.1186/1471-2377-14-64

91. Song F, Poljak A, Kochan NA, Raftery M, Brodaty H, Smythe GA, et al. Plasma protein profiling of mild cognitive impairment and Alzheimer's 
disease using iTRAQ quantitative proteomics. Proteome Sci (2014) 12:5. doi:10.1186/1477-5956-12-5

92. Baranowska-Bik A, Bik W, Styczynska M, Chodakowska-Zebrowska M, Barcikowska M, Wolinska-Witort E, et al. Plasma leptin levels and free leptin index in women with Alzheimer's disease. Neuropeptides (2015) 52:73-8. doi:10.1016/j.npep.2015.05.006

93. Hare DJ, Doecke JD, Faux NG, Rembach A, Volitakis I, Fowler CJ, et al. Decreased plasma iron in Alzheimer's disease is due to transferrin desaturation. ACS Chem Neurosci (2015) 6:398-402. doi:10.1021/cn5003557

94. Muenchhoff J, Poljak A, Song F, Raftery M, Brodaty H, Duncan M, et al. Plasma protein profiling of mild cognitive impairment and Alzheimer's disease across two independent cohorts. J Alzheimers Dis (2015) 43:1355-73. doi:10.3233/JAD-141266

95. Qin W, Jia X, Wang F, Zuo X, Wu L, Zhou A, et al. Elevated plasma angiogenesis factors in Alzheimer's disease. J Alzheimers Dis (2015) 45:245-52. doi:10.3233/JAD-142409

96. Hye A, Lynham S, Thambisetty M, Causevic M, Campbell J, Byers HL, et al. Proteome-based plasma biomarkers for Alzheimer's disease. Brain (2006) 129:3042-50. doi:10.1093/brain/awl279

97. Ray S, Britschgi M, Herbert C, Takeda-Uchimura Y, Boxer A, Blennow K, et al. Classification and prediction of clinical Alzheimer's diagnosis based on plasma signaling proteins. Nat Med (2007) 13:1359-62. doi:10.1038/nm1653

98. Ait-Ghezala G, Abdullah L, Volmar CH, Paris D, Luis CA, Quadros A, et al. Diagnostic utility of APOE, soluble CD40, CD40L, and Abeta1-40 levels in plasma in Alzheimer's disease. Cytokine (2008) 44:283-7. doi:10.1016/j. cyto.2008.08.013

99. Cutler P, Akuffo EL, Bodnar WM, Briggs DM, Davis JB, Debouck CM, et al. Proteomic identification and early validation of complement 1 inhibitor and pigment epithelium-derived factor: two novel biomarkers of Alzheimer's disease in human plasma. Proteomics Clin Appl (2008) 2:467-77. doi:10.1002/ prca.200780101

100. Gomez Ravetti M, Moscato P. Identification of a 5-protein biomarker molecular signature for predicting Alzheimer's disease. PLoS One (2008) 3:e3111. doi:10.1371/journal.pone.0003111

101. O’Bryant SE, Xiao G, Barber R, Reisch J, Doody R, Fairchild T, et al. A serum protein-based algorithm for the detection of Alzheimer disease. Arch Neurol (2010) 67:1077-81. doi:10.1001/archneurol.2010.215

102. Laske C, Leyhe T, Stransky E, Hoffmann N, Fallgatter AJ, Dietzsch J. Identification of a blood-based biomarker panel for classification of Alzheimer's disease. Int J Neuropsychopharmacol (2011) 14:1147-55. doi:10.1017/S1461145711000459

103. Marksteiner J, Kemmler G, Weiss EM, Knaus G, Ullrich C, Mechtcheriakov $\mathrm{S}$, et al. Five out of 16 plasma signaling proteins are enhanced in plasma of patients with mild cognitive impairment and Alzheimer's disease. Neurobiol Aging (2011) 32:539-40. doi:10.1016/j.neurobiolaging.2009.03.011

104. O’Bryant SE, Xiao G, Barber R, Huebinger R, Wilhelmsen K, Edwards M, et al. A blood-based screening tool for Alzheimer's disease that spans serum and plasma: findings from TARC and ADNI. PLoS One (2011) 6:e28092. doi:10.1371/journal.pone.0028092

105. O’Bryant SE, Xiao G, Barber R, Reisch J, Hall J, Cullum CM, et al. A bloodbased algorithm for the detection of Alzheimer's disease. Dement Geriatr Cogn Disord (2011) 32:55-62. doi:10.1159/000330750

106. Doecke JD, Laws SM, Faux NG, Wilson W, Burnham SC, Lam CP, et al. Blood-based protein biomarkers for diagnosis of Alzheimer disease. Arch Neurol (2012) 69:1318-25. doi:10.1001/archneurol.2012.1282

107. Hu WT, Holtzman DM, Fagan AM, Shaw LM, Perrin R, Arnold SE, et al. Plasma multianalyte profiling in mild cognitive impairment and Alzheimer disease. Neurology (2012) 79:897-905. doi:10.1212/WNL.0b013e318266fa70

108. Soares HD, Potter WZ, Pickering E, Kuhn M, Immermann FW, Shera DM, et al. Plasma biomarkers associated with the apolipoprotein E genotype and Alzheimer disease. Arch Neurol (2012) 69:1310-7. doi:10.1001/ archneurol.2012.1070

109. Guo LH, Alexopoulos P, Wagenpfeil S, Kurz A, Perneczky R. Plasma proteomics for the identification of Alzheimer disease. Alzheimer Dis Assoc Disord (2013) 27:337-42. doi:10.1097/WAD.0b013e31827b60d2

110. Liang F, Jia J, Wang S, Qin W, Liu G. Decreased plasma levels of soluble low density lipoprotein receptor-related protein-1 (sLRP) and the soluble form of the receptor for advanced glycation end products (sRAGE) in the clinical diagnosis of Alzheimer's disease. J Clin Neurosci (2013) 20:357-61. doi:10.1016/j.jocn.2012.06.005

111. Llano DA, Devanarayan V, Simon AJ. Evaluation of plasma proteomic data for Alzheimer disease state classification and for the prediction of progression from mild cognitive impairment to Alzheimer disease. Alzheimer Dis Assoc Disord (2013) 27:233-43. doi:10.1097/WAD.0b013e31826d597a

112. Zhang J, Jia J, Qin W, Wang S. Combination of plasma tumor necrosis factor receptors signaling proteins, beta-amyloid and apolipoprotein $\mathrm{E}$ for the detection of Alzheimer's disease. Neurosci Lett (2013) 541:99-104. doi:10.1016/j.neulet.2013.03.007

113. Marksteiner J, Imarhiagbe D, Defrancesco $M$, Deisenhammer EA, Kemmler G, Humpel C. Analysis of 27 vascular-related proteins reveals that NT-proBNP is a potential biomarker for Alzheimer's disease and mild cognitive impairment: a pilot-study. Exp Gerontol (2014) 50:114-21. doi:10.1016/j. exger.2013.12.001

114. Agarwal S, Ghanty P, Pal NR. Identification of a small set of plasma signalling proteins using neural network for prediction of Alzheimer's disease. Bioinformatics (2015) 31:2505-13. doi:10.1093/ bioinformatics/btv173

115. Delaby C, Gabelle A, Blum D, Schraen-Maschke S, Moulinier A, Boulanghien J, et al. Central nervous system and peripheral inflammatory processes in Alzheimer's disease: biomarker profiling approach. Front Neurol (2015) 6:181. doi:10.3389/fneur.2015.00181

116. Peng M, Jia J, Qin W. Plasma gelsolin and matrix metalloproteinase 3 as potential biomarkers for Alzheimer disease. Neurosci Lett (2015) 595:116-21. doi:10.1016/j.neulet.2015.04.014

117. Uchida K, Shan L, Suzuki H, Tabuse Y, Nishimura Y, Hirokawa Y, et al. Amyloid- $\beta$ sequester proteins as blood-based biomarkers of cognitive decline. Alzheimers Dement (2015) 1:270-80. doi:10.1016/j.dadm.2015.04.003

118. Zhao X, Lejnine S, Spond J, Zhang C, Ramaraj TC, Holder DJ, et al. A candidate plasma protein classifier to identify Alzheimer's disease. J Alzheimers Dis (2015) 43:549-63. doi:10.3233/JAD-141149

119. Zurbig P, Jahn $\mathrm{H}$. Use of proteomic methods in the analysis of human body fluids in Alzheimer research. Electrophoresis (2012) 33:3617-30. doi:10.1002/ elps. 201200360

120. Lista S, Faltraco F, Prvulovic D, Hampel H. Blood and plasma-based proteomic biomarker research in Alzheimer's disease. Prog Neurobiol (2013) 10(1-102):1-17. doi:10.1016/j.pneurobio.2012.06.007

121. Soares HD, Chen Y, Sabbagh M, Roher A, Schrijvers E, Breteler M. Identifying early markers of Alzheimer's disease using quantitative multiplex proteomic immunoassay panels. Ann N Y Acad Sci (2009) 1180:56-67. doi:10.1111/j.1749-6632.2009.05066.x

122. Bjorkqvist M, Ohlsson M, Minthon L, Hansson O. Evaluation of a previously suggested plasma biomarker panel to identify Alzheimer's disease. PLoS One (2012) 7:e29868. doi:10.1371/journal.pone.0029868

123. Yang H, Lyutvinskiy Y, Herukka SK, Soininen H, Rutishauser D, Zubarev RA. Prognostic polypeptide blood plasma biomarkers of Alzheimer's disease progression. J Alzheimers Dis (2014) 40:659-66. doi:10.3233/JAD-132102

124. Hye A, Riddoch-Contreras J, Baird AL, Ashton NJ, Bazenet C, Leung R, et al. Plasma proteins predict conversion to dementia from prodromal disease. Alzheimers Dement (2014) 10:799-807. doi:10.1016/j.jalz.2014.05.1749

125. Apostolova LG, Hwang KS, Avila D, Elashoff D, Kohannim O, Teng E, et al. Brain amyloidosis ascertainment from cognitive, imaging, and peripheral blood protein measures. Neurology (2015) 84:729-37. doi:10.1212/ WNL.0000000000001231

126. Doody RS, Thomas RG, Farlow M, Iwatsubo T, Vellas B, Joffe S, et al. Phase 3 trials of solanezumab for mild-to-moderate Alzheimer's disease. $N$ Engl J Med (2014) 370:311-21. doi:10.1056/NEJMoa1312889

127. Salloway S, Sperling R, Fox NC, Blennow K, Klunk W, Raskind M, et al. Two phase 3 trials of bapineuzumab in mild-to-moderate Alzheimer's disease. $N$ Engl J Med (2014) 370:322-33. doi:10.1056/NEJMoa1304839

128. Thambisetty M, Simmons A, Velayudhan L, Hye A, Campbell J, Zhang Y, et al. Association of plasma clusterin concentration with severity, pathology, and progression in Alzheimer disease. Arch Gen Psychiatry (2010) 67:739-48. doi:10.1001/archgenpsychiatry.2010.78

129. Thambisetty M, Simmons A, Hye A, Campbell J, Westman E, Zhang Y, et al. Plasma biomarkers of brain atrophy in Alzheimer's disease. PLoS One (2011) 6:e28527. doi:10.1371/journal.pone.0028527 
130. Song F, Poljak A, Crawford J, Kochan NA, Wen W, Cameron B, et al. Plasma apolipoprotein levels are associated with cognitive status and decline in a community cohort of older individuals. PLoS One (2012) 7:e34078. doi:10.1371/journal.pone.0034078

131. Thambisetty M, An Y, Kinsey A, Koka D, Saleem M, Guntert A, et al. Plasma clusterin concentration is associated with longitudinal brain atrophy in mild cognitive impairment. Neuroimage (2012) 59:212-7. doi:10.1016/j. neuroimage.2011.07.056

132. Leung R, Proitsi P, Simmons A, Lunnon K, Guntert A, Kronenberg D, et al. Inflammatory proteins in plasma are associated with severity of Alzheimer's disease. PLoS One (2013) 8:e64971. doi:10.1371/journal.pone.0064971

133. Toledo JB, Da X, Bhatt P, Wolk DA, Arnold SE, Shaw LM, et al. Relationship between plasma analytes and SPARE-AD defined brain atrophy patterns in ADNI. PLoS One (2013) 8:e55531. doi:10.1371/journal.pone.0055531

134. Sattlecker M, Kiddle SJ, Newhouse S, Proitsi P, Nelson S, Williams S, et al. Alzheimer's disease biomarker discovery using SOMAscan multiplexed protein technology. Alzheimers Dement (2014) 10:724-34. doi:10.1016/j. jalz.2013.09.016

135. Teng E, Chow N, Hwang KS, Thompson PM, Gylys KH, Cole GM, et al. Low plasma ApoE levels are associated with smaller hippocampal size in the Alzheimer's disease neuroimaging initiative cohort. Dement Geriatr Cogn Disord (2015) 39:154-66. doi:10.1159/000368982

136. Velayudhan L, Killick R, Hye A, Kinsey A, Guntert A, Lynham S, et al. Plasma transthyretin as a candidate marker for Alzheimer's disease. J Alzheimers Dis (2012) 28:369-75. doi:10.3233/JAD-2011-110611

137. Thambisetty M, Tripaldi R, Riddoch-Contreras J, Hye A, An Y, Campbell J, et al. Proteome-based plasma markers of brain amyloid-beta deposition in non-demented older individuals. J Alzheimers Dis (2010) 22:1099-109. doi:10.3233/JAD-2010-101350

138. Kiddle SJ, Thambisetty M, Simmons A, Riddoch-Contreras J, Hye A, Westman E, et al. Plasma based markers of [11C] PiB-PET brain amyloid burden. PLoS One (2012) 7:e44260. doi:10.1371/journal.pone.0044260

139. Burnham SC, Faux NG, Wilson W, Laws SM, Ames D, Bedo J, et al. A bloodbased predictor for neocortical Abeta burden in Alzheimer's disease: results from the AIBL study. Mol Psychiatry (2014) 19:519-26. doi:10.1038/mp.2013.40

140. Ashton NJ, Kiddle SJ, Graf J, Ward M, Baird AL, Hye A, et al. Blood protein predictors of brain amyloid for enrichment in clinical trials? Alzheimers Dement (Amst) (2015) 1:48-60. doi:10.1016/j.dadm.2014.11.005

141. Hwang KS, Lazaris AS, Eastman JA, Teng E, Thompson PM, Gylys KH, et al. Plasma BDNF levels associate with Pittsburgh compound B binding in the brain. Alzheimers Dement (Amst) (2015) 1:187-93. doi:10.1016/j. dadm.2015.01.005

142. Voyle N, Baker D, Burnham SC, Covin A, Zhang Z, Sangurdekar DP, et al. Blood protein markers of neocortical amyloid-beta burden: a candidate study using SOMAscan technology. J Alzheimers Dis (2015) 46:947-61. doi:10.3233/JAD-150020

143. Lovestone S, Francis P, Kloszewska I, Mecocci P, Simmons A, Soininen H, et al. AddNeuroMed - the European collaboration for the discovery of novel biomarkers for Alzheimer's disease. Ann N Y Acad Sci (2009) 1180:36-46. doi:10.1111/j.1749-6632.2009.05064.x

144. Resnick SM, Goldszal AF, Davatzikos C, Golski S, Kraut MA, Metter EJ, et al. One-year age changes in MRI brain volumes in older adults. Cereb Cortex (2000) 10:464-72. doi:10.1093/cercor/10.5.464

145. Jongbloed W, Van Dijk KD, Mulder SD, van de Berg WD, Blankenstein MA, van der Flier W, et al. Clusterin levels in plasma predict cognitive decline and progression to Alzheimer's disease. J Alzheimers Dis (2015) 46:1103-10. doi:10.3233/JAD-150036

146. Wilson MR, Yerbury JJ, Poon S. Potential roles of abundant extracellular chaperones in the control of amyloid formation and toxicity. Mol Biosyst (2008) 4:42-52. doi:10.1039/B712728F

147. DeMattos RB, Cirrito JR, Parsadanian M, May PC, O’dell MA, Taylor JW, et al. ApoE and clusterin cooperatively suppress Abeta levels and deposition: evidence that ApoE regulates extracellular Abeta metabolism in vivo. Neuron (2004) 41:193-202. doi:10.1016/S0896-6273(03)00850-X

148. Yerbury JJ, Poon S, Meehan S, Thompson B, Kumita JR, Dobson CM, et al. The extracellular chaperone clusterin influences amyloid formation and toxicity by interacting with prefibrillar structures. FASEB J (2007) 21:2312-22. doi:10.1096/fj.06-7986com
149. Nuutinen T, Suuronen T, Kauppinen A, Salminen A. Clusterin: a forgotten player in Alzheimer's disease. Brain Res Rev (2009) 61:89-104. doi:10.1016/j. brainresrev.2009.05.007

150. Yu JT, Tan L. The role of clusterin in Alzheimer's disease: pathways, pathogenesis, and therapy. Mol Neurobiol (2012) 45:314-26. doi:10.1007/ s12035-012-8237-1

151. Li X, Ma Y, Wei X, Li Y, Wu H, Zhuang J, et al. Clusterin in Alzheimer's disease: a player in the biological behavior of amyloid-beta. Neurosci Bull (2014) 30:162-8. doi:10.1007/s12264-013-1391-2

152. Killick R, Ribe EM, Al-Shawi R, Malik B, Hooper C, Fernandes C, et al. Clusterin regulates beta-amyloid toxicity via Dickkopf-1-driven induction of the wnt-PCP-JNK pathway. Mol Psychiatry (2014) 19:88-98. doi:10.1038/ mp. 2012.163

153. Harold D, Abraham R, Hollingworth P, Sims R, Gerrish A, Hamshere $\mathrm{ML}$, et al. Genome-wide association study identifies variants at CLU and PICALM associated with Alzheimer's disease. Nat Genet (2009) 41:1088-93. doi:10.1038/ng1009-1156d

154. Lambert JC, Heath S, Even G, Campion D, Sleegers K, Hiltunen M, et al. Genome-wide association study identifies variants at CLU and CR1 associated with Alzheimer's disease. Nat Genet (2009) 41:1094-9. doi:10.1038/ ng.439

155. Thambisetty M, Beason-Held LL, An Y, Kraut M, Nalls M, Hernandez DG, et al. Alzheimer risk variant CLU and brain function during aging. Biol Psychiatry (2013) 73:399-405. doi:10.1016/j.biopsych.2012.05.026

156. Roussotte FF, Gutman BA, Madsen SK, Colby JB, Thompson PM; Alzheimer's Disease Neuroimaging Initiative. Combined effects of Alzheimer risk variants in the CLU and ApoE genes on ventricular expansion patterns in the elderly. J Neurosci (2014) 34:6537-45. doi:10.1523/ JNEUROSCI.5236-13.2014

157. Lewis TL, Cao D, Lu H, Mans RA, Su YR, Jungbauer L, et al. Overexpression of human apolipoprotein A-I preserves cognitive function and attenuates neuroinflammation and cerebral amyloid angiopathy in a mouse model of Alzheimer disease. J Biol Chem (2010) 285:36958-68. doi:10.1074/jbc. M110.127829

158. Lopez MF, Krastins B, Ning M. The role of apolipoprotein E in neurodegeneration and cardiovascular disease. Expert Rev Proteomics (2014) 11:371-81. doi:10.1586/14789450.2014.901892

159. Akiyama H, Barger S, Barnum S, Bradt B, Bauer J, Cole GM, et al. Inflammation and Alzheimer's disease. Neurobiol Aging (2000) 21:383-421. doi:10.1016/S0197-4580(00)00124-X

160. Mrak RE, Griffin WS. Potential inflammatory biomarkers in Alzheimer's disease. J Alzheimers Dis (2005) 8:369-75.

161. Ellis KA, Bush AI, Darby D, De Fazio D, Foster J, Hudson P, et al. The Australian imaging, biomarkers and lifestyle (AIBL) study of aging: methodology and baseline characteristics of 1112 individuals recruited for a longitudinal study of Alzheimer's disease. Int Psychogeriatr (2009) 21:672-87. doi:10.1017/S1041610209009405

162. Walsh DM, Selkoe DJ. A beta oligomers - a decade of discovery. J Neurochem (2007) 101:1172-84. doi:10.1111/j.1471-4159.2006.04426.x

163. Sokoloff L. Relationships among local functional activity, energy metabolism, and blood flow in the central nervous system. Fed Proc (1981) 40:2311-6.

164. Bohnen NI, Djang DS, Herholz K, Anzai Y, Minoshima S. Effectiveness and safety of 18 F-FDG PET in the evaluation of dementia: a review of the recent literature. J Nucl Med (2012) 53:59-71. doi:10.2967/ jnumed.111.096578

165. Mosconi L, Tsui WH, Herholz K, Pupi A, Drzezga A, Lucignani G, et al. Multicenter standardized 18F-FDG PET diagnosis of mild cognitive impairment, Alzheimer's disease, and other dementias. J Nucl Med (2008) 49:390-8. doi:10.2967/jnumed.107.045385

166. Morbelli S, Piccardo A, Villavecchia G, Dessi B, Brugnolo A, Piccini A, et al. Mapping brain morphological and functional conversion patterns in amnestic MCI: a voxel-based MRI and FDG-PET study. Eur J Nucl Med Mol Imaging (2010) 37:36-45. doi:10.1007/s00259-009-1218-6

167. Laforce R Jr, Tosun D, Ghosh P, Lehmann M, Madison CM, Weiner MW, et al. Parallel ICA of FDG-PET and PiB-PET in three conditions with underlying Alzheimer's pathology. Neuroimage Clin (2014) 4:508-16. doi:10.1016/j. nicl.2014.03.005 
168. Shokouhi S, Claassen D, Riddle W. Imaging brain metabolism and pathology in Alzheimer's disease with positron emission tomography. J Alzheimers Dis Parkinsonism (2014) 4:143. doi:10.4172/2161-0460.1000143

169. Fodero-Tavoletti MT, Okamura N, Furumoto S, Mulligan RS, Connor AR, McLean CA, et al. 18F-THK523: a novel in vivo tau imaging ligand for Alzheimer's disease. Brain (2011) 134:1089-100. doi:10.1093/brain/awr038

170. Chien DT, Bahri S, Szardenings AK, Walsh JC, Mu F, Su MY, et al. Early clinical PET imaging results with the novel PHF-tau radioligand [F-18]-T807. J Alzheimers Dis (2013) 34:457-68. doi:10.3233/JAD-122059

171. Chien DT, Szardenings AK, Bahri S, Walsh JC, Mu F, Xia C, et al. Early clinical PET imaging results with the novel PHF-tau radioligand [F18]-T808. J Alzheimers Dis (2014) 38:171-84. doi:10.3233/JAD-130098

172. Han X, Rozen S, Boyle SH, Hellegers C, Cheng H, Burke JR, et al. Metabolomics in early Alzheimer's disease: identification of altered plasma sphingolipidome using shotgun lipidomics. PLoS One (2011) 6:e21643. doi:10.1371/journal. pone.0021643

173. Gonzalez-Dominguez R, Garcia A, Garcia-Barrera T, Barbas C, GomezAriza JL. Metabolomic profiling of serum in the progression of Alzheimer's disease by capillary electrophoresis-mass spectrometry. Electrophoresis (2014) 35:3321-30. doi:10.1002/elps.201400196

174. Mapstone M, Cheema AK, Fiandaca MS, Zhong X, Mhyre TR, Macarthur LH, et al. Plasma phospholipids identify antecedent memory impairment in older adults. Nat Med (2014) 20:415-8. doi:10.1038/nm.3466
175. Whiley L, Sen A, Heaton J, Proitsi P, Garcia-Gomez D, Leung $\mathrm{R}$, et al. Evidence of altered phosphatidylcholine metabolism in Alzheimer's disease. Neurobiol Aging (2014) 35:271-8. doi:10.1016/j. neurobiolaging.2013.08.001

176. Desire L, Blondiaux E, Carriere J, Haddad R, Sol O, Fehlbaum-Beurdeley P, et al. Blood transcriptomic biomarkers of Alzheimer's disease patients treated with EHT 0202. J Alzheimers Dis (2013) 34:469-83. doi:10.3233/JAD-121501

177. Lunnon K, Sattlecker M, Furney SJ, Coppola G, Simmons A, Proitsi P, et al. A blood gene expression marker of early Alzheimer's disease. J Alzheimers Dis (2013) 33:737-53. doi:10.3233/JAD-2012-121363

Conflict of Interest Statement: Simon Lovestone is named as an inventor on biomarker intellectual property patent protected by Proteome Sciences and Kings College London. Alison L. Baird and Sarah Westwood have no conflict of interest to declare.

Copyright (c) 2015 Baird, Westwood and Lovestone. This is an open-access article distributed under the terms of the Creative Commons Attribution License (CC BY). The use, distribution or reproduction in other forums is permitted, provided the original author(s) or licensor are credited and that the original publication in this journal is cited, in accordance with accepted academic practice. No use, distribution or reproduction is permitted which does not comply with these terms. 